\title{
Chronology of subduction and collision along the Izmir-Ankara suture in Western Anatolia: records from the Central Sakarya Basin
}

Faruk Ocakoğlu, Aynur Hakyemez, Sanem Açıkalın, Sevinç Özkan Altıner, Yeşim Büyükmeriç, Alexis Licht, Huriye Demircan, Ümit Şafak, Ayşegül Yıldız, İsmail Ömer Yilmaz, Michael Wagreich \& Clay Campbell

To cite this article: Faruk Ocakoğlu, Aynur Hakyemez, Sanem Açıkalın, Sevinç Özkan Altıner, Yeșim Büyükmeriç, Alexis Licht, Huriye Demircan, Ümit Șafak, Ayșegül Yıldız, İsmail Ömer Yilmaz, Michael Wagreich \& Clay Campbell (2018): Chronology of subduction and collision along the İzmirAnkara suture in Western Anatolia: records from the Central Sakarya Basin, International Geology Review, DOI: 10.1080/00206814.2018.1507009

To link to this article: https://doi.org/10.1080/00206814.2018.1507009

View supplementary material $\asymp$

Published online: 22 Aug 2018.

Submit your article to this journal $₫$

Цll Article views: 58

View Crossmark data $\nearrow$ 


\title{
Chronology of subduction and collision along the İzmir-Ankara suture in Western Anatolia: records from the Central Sakarya Basin
}

\author{
Faruk Ocakoğlu (i] ${ }^{\mathrm{a}}$, Aynur Hakyemez ${ }^{\mathrm{b}}$, Sanem Açıkalınc, Sevinç Özkan Altıner ${ }^{\mathrm{d}}$, Yeşim Büyükmeriçe, Alexis Licht ${ }^{\mathrm{f}}$, \\ Huriye Demircan ${ }^{b}$, Ümit Şafak ${ }^{g}$, Ayşegül Yıldız ${ }^{h}$ İsmail Ömer Yilmaz ${ }^{d}$, Michael Wagreich and Clay Campbellj

\begin{abstract}
${ }^{a}$ Department of Geological Engineering, Eskişehir Osmangazi University, Eskişehir, Turkey; ${ }^{\text {b}}$ Department of Geological Research, General Directorate of Mineral Research and Exploration (MTA), Ankara, Turkey; 'Department of Civil Engineering and Geosciences, Newcastle University, Newcastle, UK; ${ }^{d}$ Department of Geological Engineering, Middle East Technical University, Ankara, Turkey; ${ }^{e}$ Department of

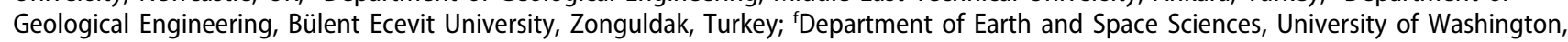

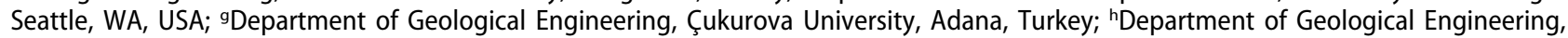
Aksaray University, Aksaray, Turkey; 'Department for Geodynamics and Sedimentology, University of Vienna, Vienna, Australia; 'Department of Geology, University of Kansas, Lawrence, KS, USA
\end{abstract}

\begin{abstract}
Western Anatolia is a complex assemblage of terranes, including the Sakarya Terrane and the Tauride-Anatolide Platform that collided during the late Cretaceous and Palaeogene (80-25 Ma) after the closure of the Izmir-Ankara Ocean. Determining the precise timing at which this ocean closed is particularly important to test kinematic reconstructions and geodynamic models of the Mediterranean region, and the chronology of suturing and its mechanisms remain controversial. Here, we document the Cretaceous-Eocene sedimentary history of the Central Sakarya Basin, along the northern margin of the Neotethys Ocean, via various approaches including biostratigraphy, geochronology, and sedimentology. Two high-resolution sections from the Central Sakarya Basin show that pelagic carbonate sedimentation shifted to rapid siliciclastic deposition in the early Campanian ( $79.6 \mathrm{Ma}$ ), interpreted to be a result of the build-up of the accretionary prism at the southern margin of the Sakarya Terrane. Rapid onset of deltaic progradation and an increase in accumulation rates in the late Danian $(\sim 61 \mathrm{Ma})$, as well as a local angular unconformity are attributed to the onset of collision between the Sakarya Terrane and the TaurideAnatolide Platform. Thus, our results indicate that though deformation of the subduction margin in Western Anatolia started as early as the Campanian, the closure of the Izmir-Ankara Ocean was only achieved by the early Palaeocene.
\end{abstract}

\section{ARTICLE HISTORY}

Received 30 April 2018

Accepted 29 July 2018

\section{KEYWORDS}

Basin subsidence; biostratigraphy; collision; İzmir-Ankara Suture; sediment flux; tectonics and sedimentation

\section{Introduction}

Early regional geological syntheses of Turkey (e.g., Saner 1980; Şengör and Yılmaz 1981) have shown that Central Anatolia is a complex assemblage of terranes, including the Pontides to the north, and the TaurideAnatolide Platform to the south, separated by the $c a$. 2000 km long İmir-Ankara-Erzincan Suture Zone (Okay and Tüysüz 1999). Three decades of geological studies including stratigraphic, sedimentological, and tectonic approaches, as well as the application of more up-todate studies of magmatic geochemistry, geochronology, metamorphism, palaeomagnetism, and geophysics have enabled a robust and increasingly refined evolutionary picture of the Anatolian Orogeny and of its different terranes (e.g., Altıner et al. 1991; Tüysüz 1999; Göncüoğlu et al. 2000; Okay et al. 2001; Robertson and
Ustaömer 2004; Okay 2008; Genç and Tüysüz 2010; Göncüoglu et al. 2010; Altunkaynak and Dilek 2013).

The outline of the gross geological picture can be summarized as follows:

(1) The Sakarya Zone occupied the southernmost part of the Scythian Platform in the late Jurassic-earliest Cretaceous, which is the southern prolongation of the East European Craton (Okay et al. 2013)

(2) Rifting of the Pontides from the Laurasian margin during the opening of the proto-Black Sea, and further division of the Pontides into two microcontinents, the Sakarya and the Istanbul terranes, which were separated by the Intra-Pontide Ocean, where the timing of opening and suturing remain debated (Şengör and Yılmaz 1981; 
Altıner et al. 1991; Göncüoğlu et al. 2000; Göncüoglu et al. 2014)

(3) Onset of the closure of the northern branch of the Neotethys by means of two north-vergent subduction zones, one intra-oceanic, the other beneath the southern Pontides margin (Göncüoglu et al. 2010), and development of a magmatic arc on the Pontides (Okay et al. 2001)

(4) Development of the HP-LT Tavşanlı Zone in the frontal part of the Anatolide-Tauride Platform in the Cenonian-early Campanian as a result of continental subduction created by the closure of the intra-oceanic subduction zone (Okay 1984; Okay et al. 1998; Sherlock et al. 1999)

(5) Collision of the Anatolide-Tauride Platform with the Pontides during the late Cretaceous-early Eocene and closure of the northern branch of the Neotethys along the Izmir-Ankara-Suture Zone (Okay and Tüysüz 1999)

(6) Development of early-middle Eocene magmatism related to slab-break-off beneath the Sakarya Terrane (Altunkaynak and Dilek 2013; Kasapoğlu et al. 2016).

Timing of suturing and collision along the IzmirAnkara Suture has been hotly debated in the literature and remains a controversial issue, with closure estimates varying from the late Cretaceous to the early Eocene (Göncüoğlu et al. 1996; Okay et al. 2001; Okay and Satır 2006; Leren et al. 2007; Okay 2008; Meijers et al. 2010). In Central Anatolia, palaeomagnetic data demonstrate that collision along the southern margin of the Central Pontides started in the latest Cretaceous to early Palaeocene causing oroclinal bending (Channell et al. 1996; Meijers et al. 2010). The convergence ensued throughout the Eocene and Oligocene resulting in further deformation and rotation throughout the suture zone, marked by the shift to foreland basin deposition in the Palaeocene (Ocakoğlu 1995; Nairn et al. 2013; Licht et al. 2017). Deformation reached the northern Central Pontide basins in the early Eocene (Leren et al. 2007; Hippolyte et al. 2010, 2015; Çinku et al. 2011). There is further stratigraphic and structural evidence from the Central Pontides indicating that the collision started in the late Palaeocene-early Eocene under the control of strike slip deformation, however this convergence has alternately been interpreted to be related to closure of the Intra-Pontide Suture (Catanzariti et al. 2013; Ottria et al. 2017). As for West Anatolia, onset of the collision has been suggested as either the early Palaeocene (Okay et al. 2001; Okay and Satır 2006) or the late Palaeocene- early Eocene (Okay 2008). Therefore, understanding the chronology of the collision is particularly important in order to test kinematic reconstructions, geodynamic models and palaeo-biogeographic scenarios of the Mediterranean region.

In the western Sakarya Terrane there is a narrow ( $100 \mathrm{~km}$ from north to south) and elongated basin ( $300 \mathrm{~km}$ from Bilecik in the west to the Miocene Galatian Massif in the east) parallel to Turkey's principal suture zone (Figure 1; Okay et al. 2001). This basin has various names (Mudurnu-Göynük Basin, Central Sakarya Basin) in the literature and here we prefer the Central Sakarya Basin (CSB) proposed by Altınlı (1976) for its geographical and geological connotations. The thick $(\sim 5 \mathrm{~km})$ Mesozoic-Lower Cenozoic sedimentary sequence of this basin has been the subject of many individual, however spatially limited stratigraphical and sedimentological studies (see the references in Ocakoğlu et al. 2007; Ocakoğlu and Açıkalın 2009). Basin-wide studies are scarce and lack precise geochronological and biostratigraphic constraints (Saner 1980; Şeker and Kesgin 1991; Göncüoğlu et al. 1996; Ocakoğlu et al. 2007). Geochemical, isotopic and clay mineralogic investigation of the basin-fill have been sparse and focused on the central part of the basin (Ocakoğlu and Açıkalın 2009; Açıkalın et al. 2016). These studies have shown that the basin displays frequent lateral and vertical facies changes probably controlled by its tectonic evolution.

The present study proposes a complete reassessment of the stratigraphy and sedimentology of the Upper Cretaceous-Lower Cenozoic sequence of the CSB, based on detailed sedimentary logs spread across the basin and dated with new biostratigraphic (primarily planktonic foraminifera, supplemented by nannofossil, radiolaria, mollusca, and ostracoda biostratigraphy) and geochronological constraints. The reconstructed basin-fill architecture for the CSB provides new insights that allow us to check the validity and timing of convergence events that have been previously hypothesized in the north and south Sakarya Terrane.

\section{Geological setting and stratigraphy of the CSB throughout the Upper Jurassic - Palaeogene}

The CSB opened in the early to middle Jurassic; however, most of its Jurassic and Cretaceous history is dominated by continental margin pelagic and clastic carbonate sedimentation (Altıner et al. 1991; Göncüoğlu et al. 2000; Okay et al. 2001; Yılmaz et al. 2016). During the Cenonian, the Intra-Pontide Ocean, located north of the Sakarya Terrane began to close as northward subduction initiated. Closure of the Intra- 


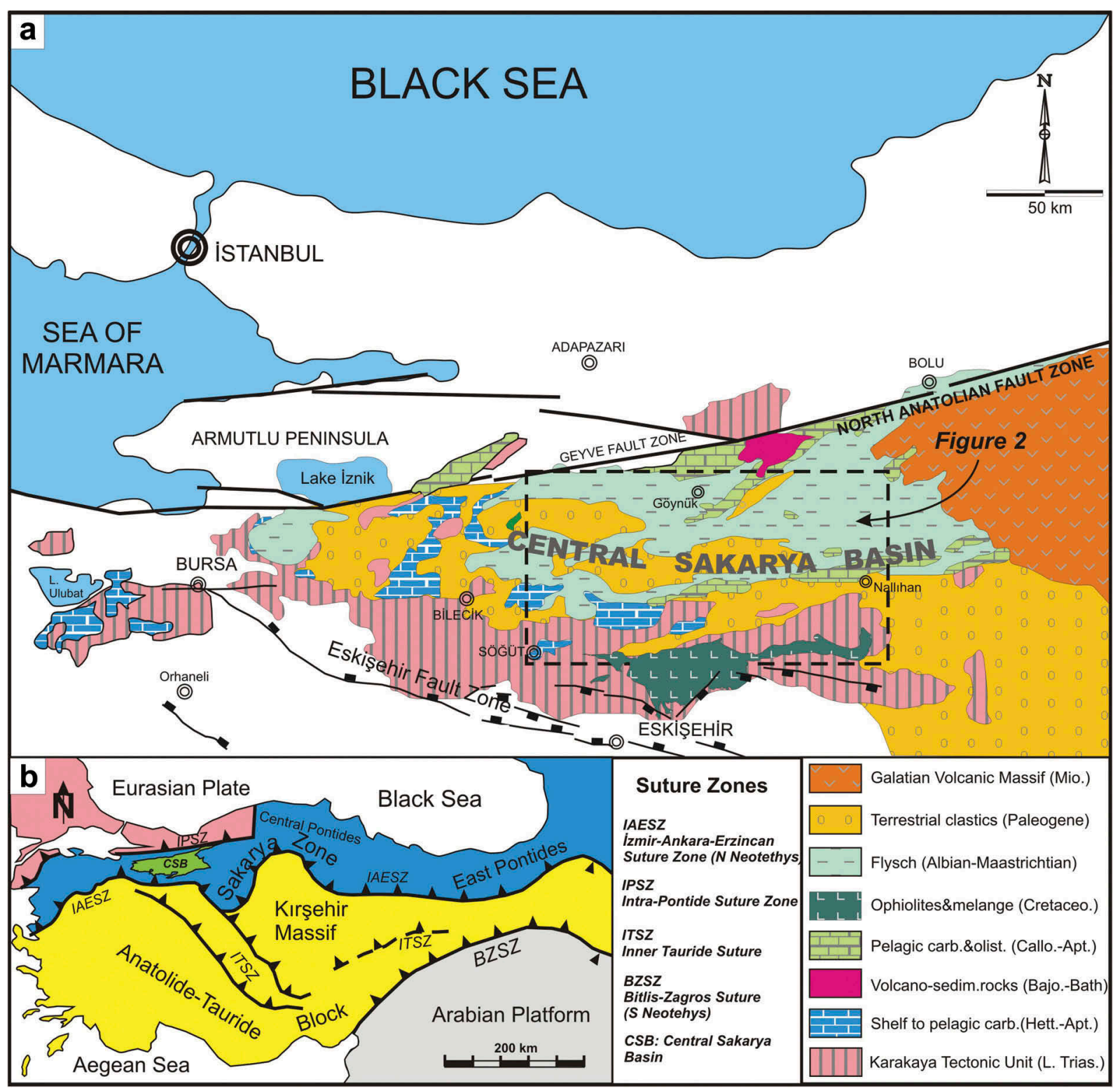

Figure 1. Simplified geological map of the NW Anatolia (A) (revised after Altıner et al. 1991; Turhan 2002). Position of the Central Sakarya Basin (CSB) with respect to the main tectonic units of Anatolia (B) (redrawn from Okay and Tüysüz 1999).

Pontide Ocean was complete by the Cenomanian (Tüysüz 1999; Robertson and Ustaömer 2004), as evidenced by associated accretionary complex development and Albian metamorphism (Okay et al. 2013) however, the timing of this closure has been recently challenged (Akbayram et al. 2016). Meanwhile, the Neotethys Ocean started subducting northwards below the southern margin of the Sakarya Terrane in the Turonian (Okay et al. 2001), and a magmatic arc was active until Campanian times throughout the Pontides (Tüysüz 1999; Okay et al. 2001; Karacık and Tüysüz 2010; Özcan et al. 2012).

A Geological map (Figure 2) as well as four synthetic stratigraphic columns are used to describe Upper
Jurassic to Eocene sedimentation (Figure 3), compiled from various local studies across the CSB. The first three columns in Figure 3 represent the western, central and eastern parts of the basin while the fourth column belongs to a subbasin that developed during the collisional stage, just in the south of the CSB.

The early to middle Jurassic history of the CSB comprises a terrestrial to shallow marine rift sequence with lesser amounts of volcanic intercalations deposited unconformably above the Variscan basement (Altıner et al. 1991; Göncüoğlu et al. 2000; Genç and Tüysüz 2010). The Upper Jurassic-Lower Cretaceous succession is dominantly composed of carbonates, and is regarded as the late stage syn-rift basin infill (Altıner et al. 1991; 

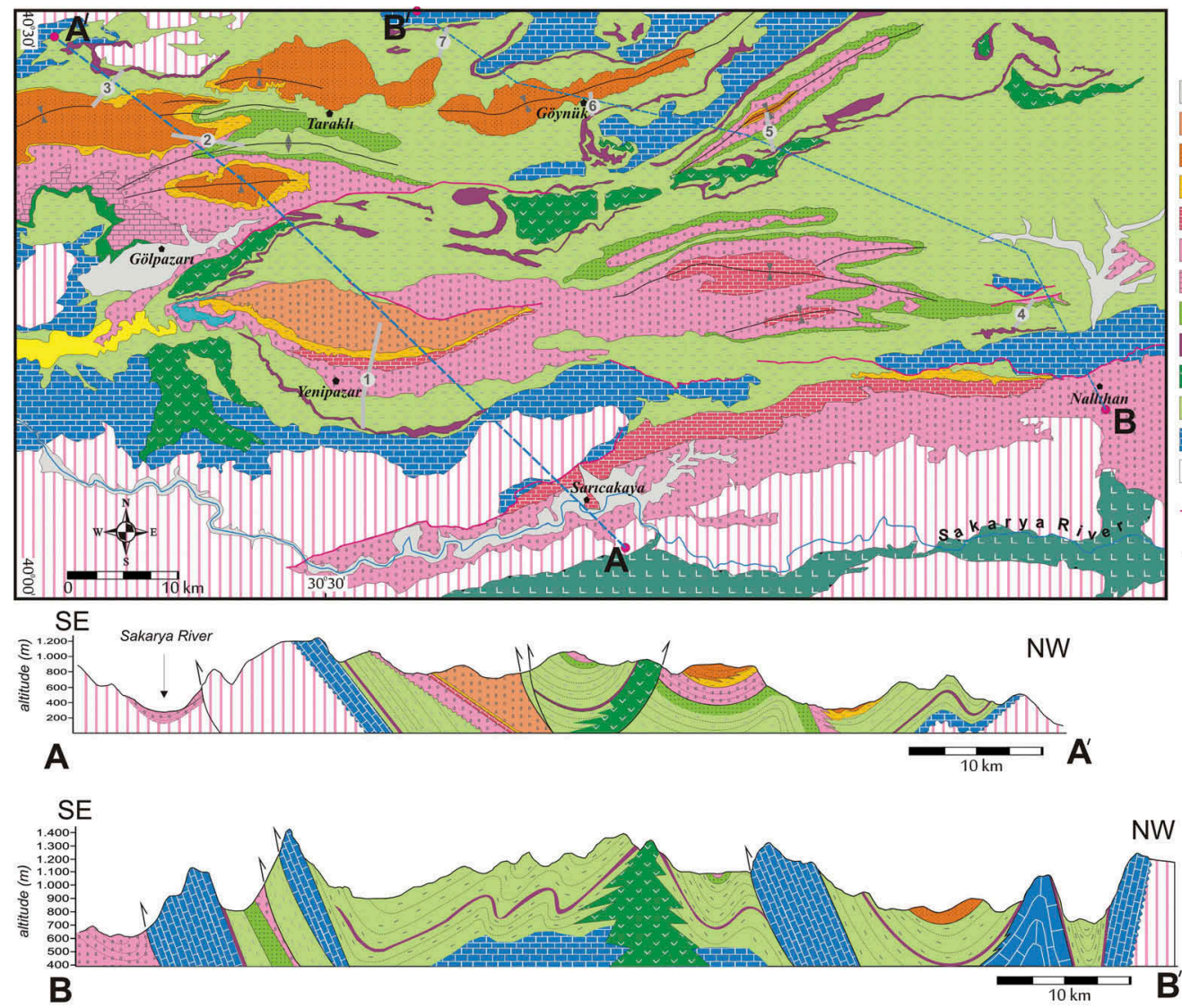

Legend

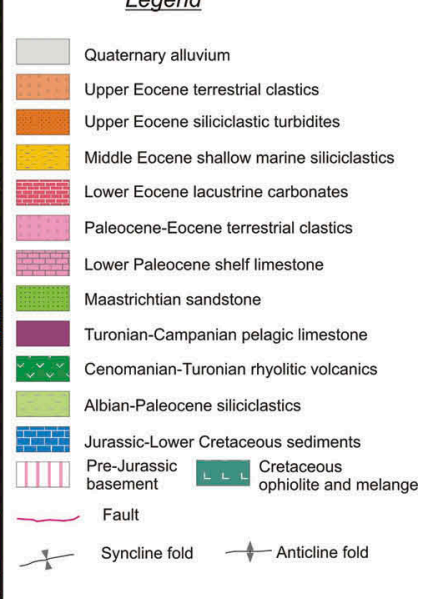

Key for

$$
\begin{aligned}
& 1 \text { Yenipazar log } \\
& 2 \text { Tarakı log } \\
& 3 \text { Akdoğan log } \\
& 4 \text { Nallıhan log } \\
& 5 \text { Okçular log } \\
& 6 \text { Göynük log } \\
& 7 \text { Ismailler log }
\end{aligned}
$$

Figure 2. Geological map (simplified after Duru et al. (2002), Gedik and Aksay (2002) and Timur and Aksay (2002)), and cross sections of the Central Sakarya Basin.

Koçyiğit et al. 1991). In the western portion of the CSB, around the town of Gölpazarı, shallow marine reefal carbonates (Bilecik $\mathrm{fm}$.) interfinger with the deeper pelagic carbonates (Soğukçam fm.) (Duru et al. 2002). Shallow marine carbonates are typically beige to pink coloured, medium to thick bedded and massive, and include varying amounts of coralgal reefal limestone (Granit and Tintant, 1960; Saner 1977, 1980; Duru et al. 2002; the references therein). In the central and eastern part of the basin, ammonite-bearing pelagic limestones were deposited in the late Jurassic-early Cretaceous. In the Nallihan area, based on distinct differences in the limestones' lithofacies and biofacies, the Yosunlukbayırı $\mathrm{fm}$. was divided in to two stratigraphic units (Altıner et al. 1991). The lower assemblage of the Yosunlukbayırı $\mathrm{fm}$. spans a time period of Tithonian to Barremian, and is composed of radiolarian-, belemniteand ammonite-bearing yellowish green clayey limestone, detrital limestone and shale at the base, followed by the upper assemblage, which consists of monotonous detrital limestone at the top (Altıner et al. 1991). Further up-section, limestone facies of mudstone and wackstone are observed with abundant slumps, and contain lesser amounts of chert nodules and calciturbidites, which collectively belong to the Soğukçam fm. Infrequent limestone olistoliths as well as abundant slumps in various levels of the Upper Jurassic-Lower Cretaceous sequence confirm the ongoing influence of extensional tectonics during deposition.

Throughout the CSB, the Albian-Campanian time interval is represented by a series of lithological associations with complex architecture whose chronology and source area characterization have been poorly defined until now: Siliciclastic turbidites and pelagic mudstones (Yenipazar and Seben formations), volcaniclastics and exceptionally preserved lava (Üzümlü member), pelagic carbonates (Değirmenözü member) and submarine canyon-fill deposits (Eymür member). The background siliciclastic deposition occurred in a distal to middle lobe setting in the western sector where Jurassic limestone olistoliths locally accompanied deposition (Saner 1977). Alternation of rhyolitic lava, tuff, agglomerate, and intervening siliciclastics of the Üzümlü member record long-lived submarine explosive volcanism (Demirkol 1977; Saner 1977; Göncüoğlu et al. 1996) during the Cenomanian across the basin. Up-section, thin-bedded, pink to beige 
fossiliferous (radiolarian and planktonic foraminifera) pelagic limestones with tuff intervals deposited in the Santonian-early Campanian (Değirmenözü member) blanket the central and eastern parts of the basin (Saner 1980; Gedik and Aksay 2002; Ocakoğlu et al. 2007). Stratigraphically upward, a Campanian terrestrial to shallow marine conglomeratic wedge (Eymür member) is well-developed near Nallıhan and Seben (Kazancı 1979; Önal et al. 1988; Şeker and Kesgin 1991), which is linked to an important relative sea-level drop during the mid-Campanian (Ocakoğlu et al. 2009, 2013).

In the CSB, facies changes in the N-S direction and the prevalence of a southern sediment source became prominent from the Maastrichtian onwards (Saner 1980; Besbelli 1991). Abundant macro-fossiliferous, medium to thick bedded deltaic sandstones (Taraklı member) and intertongued pelagic limestone intervals with abundant echinoid and planktonic forams (esp. in the Göynük area) confirm the shoaling of a marine depositional environment (Saner 1977). In the Nallıhan area, Tansel (1980) observed sandstone-conglomerate alternations in this unit and described a late Maastrichtian benthonic foraminifera biozone. The temporal framework of these deltaic sandstones and overlying terrestrial red clastics have been designated quite differently in different parts of the basin (Figure 3), likely due to the lack of geochronological characterization and correlation across the basin as well as E-W lateral facies changes.

Deltaic sandstones are gradually overlain in the E-W direction by terrestrial red clastics (Kızılçay fm), which interfinger with reefal carbonates (Selvipınar fm.) (Altınlı 1976; Saner 1977). The red clastics of the Kızılçay fm., which are dominated by conglomerates and mudstones comprise a separate member consisting of carbonate shale alternations, known as the Kabalar member. This unit is interpreted to be deposited in a lagoonal setting, based on the brahic to epineritic ostracoda content

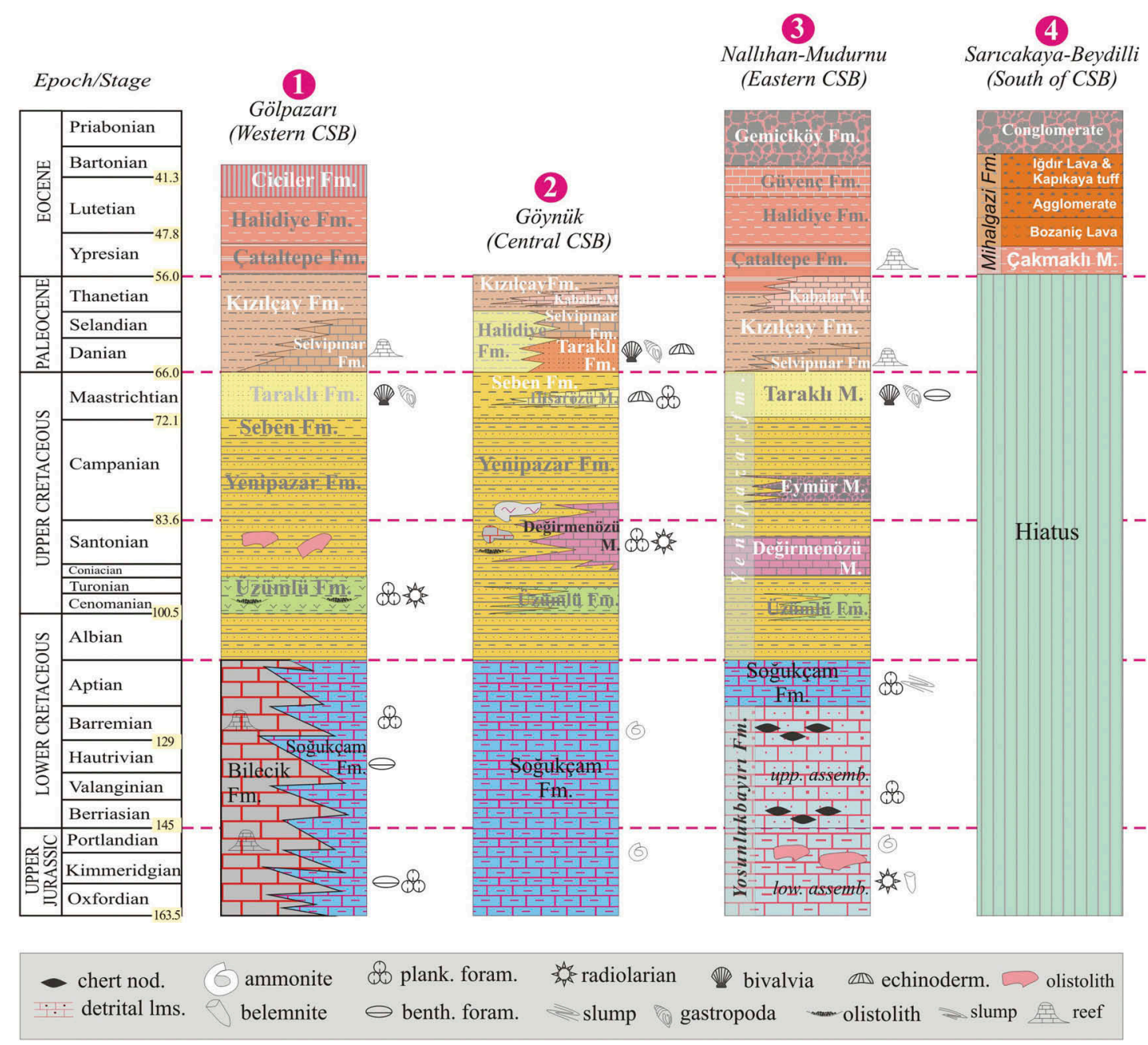

Figure 3. Generalized stratigraphic columns spanning late Jurassic to Eocene from different parts of the Central Sakarya Basin. (1) Saner (1977) and Duru et al. (2002), (2) Besbelli (1991) and Gedik and Aksay (2002), (3) Timur and Aksay (2002), Tansel (1980) and Altıner et al. (1991), and (4) Yıldız et al. (2015) and Kasapoğlu et al. (2016). 
south of the line between Gölpazarı and S. Göynük, which exhibits orbitally driven lithofacies cycles of different temporal hierarchies (Ocakoğlu et al. 2012). A marine influence is also suggested based on the geochemical data from oil shale in this unit (Sarı and Aliyev 2005).

In the Eocene, a basin-wide transgression gave rise to the deposition of a shallow marine coarse clastics with abundant molluscs and corals (Çataltepe fm.). The on-going deepening resulted in vertical and lateral facies changes to a sedimentary package composed of alternating thin to medium turbidite beds and hemipelagic muds (Halidiye $\mathrm{fm}$ ) in an overall shallow marine setting (Saner 1977; Besbelli 1991; Ocakoğlu et al. 2007). The youngest marine sediments of the CSB are lithologically highly varied, and predominantly composed of late Lutetian-aged mudstone-fossiliferous limestone alternations (Gedik and Aksay 2002). The youngest conformable unit of the CSB is the Gemiciköy Formation whose outcrops are only preserved north of Yenipazar (Figure 2). This unit gradually overlies Eocene marine clastics (Güvenç fm.), and formed from coarse-grained fluvial deposits. Up-section, the unit increases in the amount and size of reworked blocks from the Cretaceous-Palaeocene basin-fill and the basaltic lava blocks are remarkable (Eroskay 1965; Ocakoğlu et al. 2007).

The Sarıcakaya-Beydilli section in Figure 3 represents the terrain north of the south-vergent thrust zone that extends from Sarıcakaya east to Nallıhan (Figure 2). This section is composed of Lower-Middle Eocene terrestrial siliciclastics (Çakmaklı member) and an interfingered volcanic complex, deposited on the Variscan basement (Yıldiz et al. 2015). The latter is composed of basalticandesitic lava flows, andesitic-rhyolitic domes and locally agglomerates and tuffs. Detrital zircon U-Pb ages from this volcanic complex yielded ages between 51 and $47 \mathrm{Ma}$ (Kasapoğlu et al. 2016).

\section{Methods}

We measured 12 sedimentological logs between the Gölpazarı and Nallıhan towns in a $120 \mathrm{~km}$ wide area, mostly starting from the Değirmenözü Member (Turonian-Campanian) and extending as far up as possible in to the basin-fill. Thickness of the logs vary from 862 to $2370 \mathrm{~m}$. Each section is of $\mathrm{cm}$-to- $\mathrm{dm}$ resolution and encompasses various information such as lithology, sedimentary structure, macro-fossil content, palaeocurrent direction, and samples collected for biostratigraphic and geochronological dating. Here we present seven sedimentological logs, measured along two NW bearing geotraverses (Figure 2). Although simplified, lithofacies, biostratigraphy and palaeocurrent data are still visible in these sedimentological logs (Figures 4 \& 7).

Two volcaniclastic sandstone samples were selected for U-Pb dating of zircons on the Göynük Section. Zircon crystals were extracted by traditional methods of heavy mineral separation at the Department of Geology, University of Kansas. U-Pb ages were generated using laser-ablation inductively coupled plasma mass-spectrometry (LA-ICP-MS) with a laser spot diameter of $20 \mu \mathrm{m}$. Detailed methods for extraction, analysis, and data reduction can be found in Licht et al. (2017). Crystallization age for volcanic samples were calculated using TuffZirc (Ludwig 2003). The final age error calculated for each sample is the quadratic sum of the uncertainty of TuffZirc age calculation and of the systematic uncertainty during each session ( 1\%). Detailed U-Pb data are given in Supplementary Table 1.

\section{Description of the measured sections}

\subsection{Yenipazar section}

The Yenipazar Section comprises almost the complete Turonian-Eocene basin-fill and measures $2370 \mathrm{~m}$ thick (Figure 4A and SM Figure1). This section starts within the Değirmenözü Formation, an $80 \mathrm{~m}$ thick unit formed from the alternation of thin $(<5 \mathrm{~cm})$ pink limestone and red mudstone laminae in the lower part, that is dominated by red mudstones further up-section. Metric slumps are common. Two planktonic foraminifera biozones of late Santonian to early Campanian age, Dicarinella asymetrica and Globotruncanita elevata, are distinguished in the unit (Figures 4 and 5). A gradual colour change to grey and the first appearance of turbidite sandstones mark the transition to the Yenipazar Formation. The Yenipazar Formation consists of alternations of grey mudstone, thin to mediumbedded sandstone and thick to very thick green tuff. Extrabasinal conglomerates up to $5 \mathrm{~m}$ thick can sometimes accompany the sandy intervals. Conglomerate clasts (3-5 cm size) are derived from the Lower-Middle Cretaceous limestone and marl, gneiss and ultramafic fragments. Flute casts and asymmetrical ripples from diverse stratigraphical levels indicate palaeocurrents to the NE, NW and less commonly to W. Ignoring siliciclastic intercalations, the total thickness of the tuff levels reaches a maximum of $\sim 200 \mathrm{~m}$. In most cases, tuff beds have a basal conglomeratic level with mixed volcanic and siliciclastic gravels. The planktonic foraminifera content of the mudstones is very poor presumably due to frequent volcanism. 
a Yenipazar Section

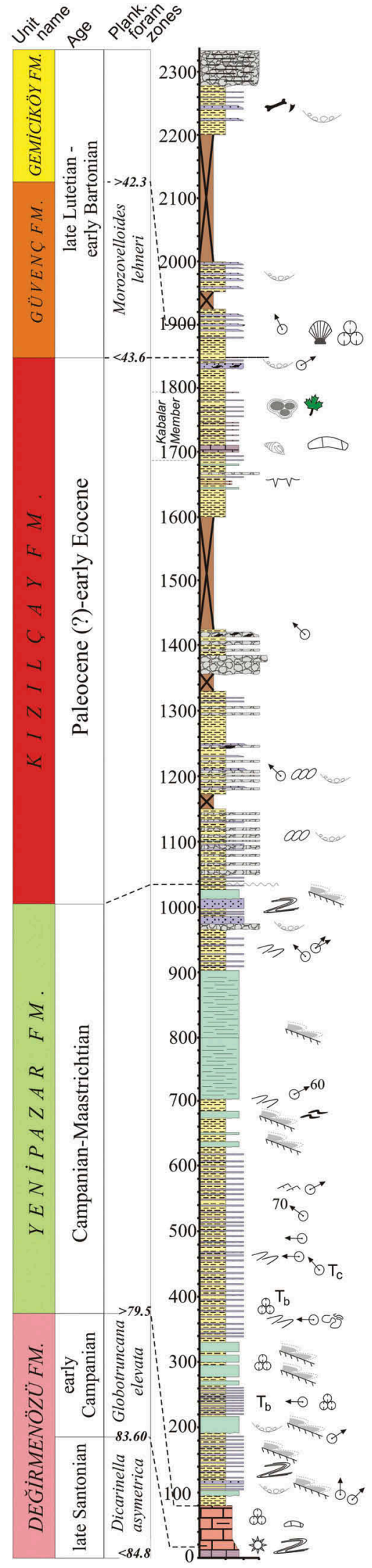

\section{b Taraklı Section}

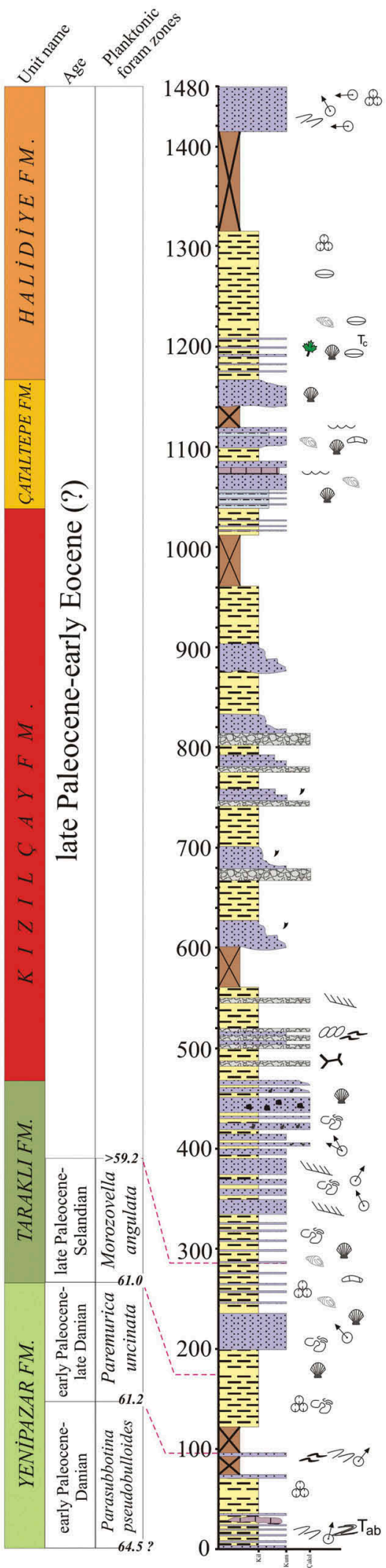

C Akdoğan Section

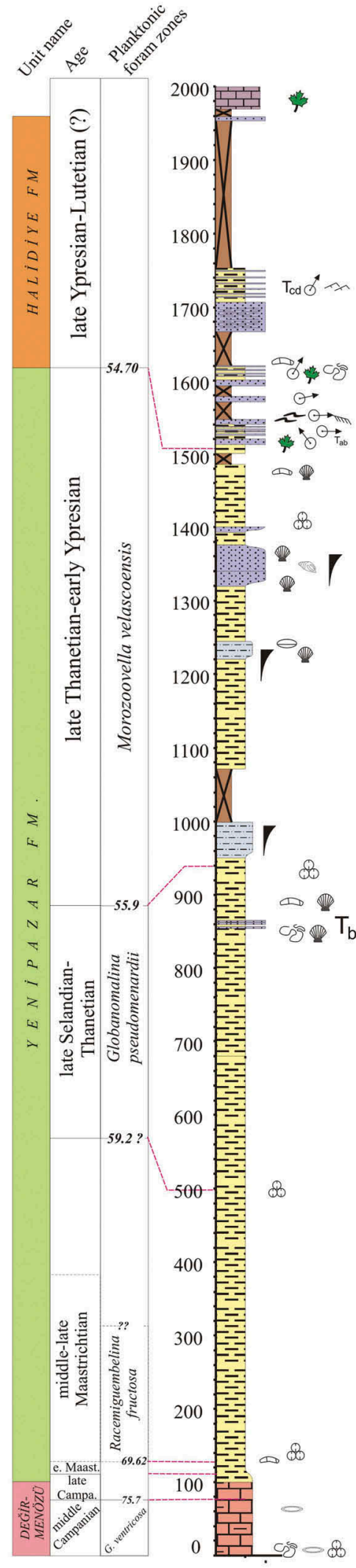

Figure 4. Detailed sedimentological logs of the Yenipazar (a), Taraklı (b) and Akdoğan (c) Sections including biostratigraphic data (see Figure 2 for location, and Figure 9 for the legend). 


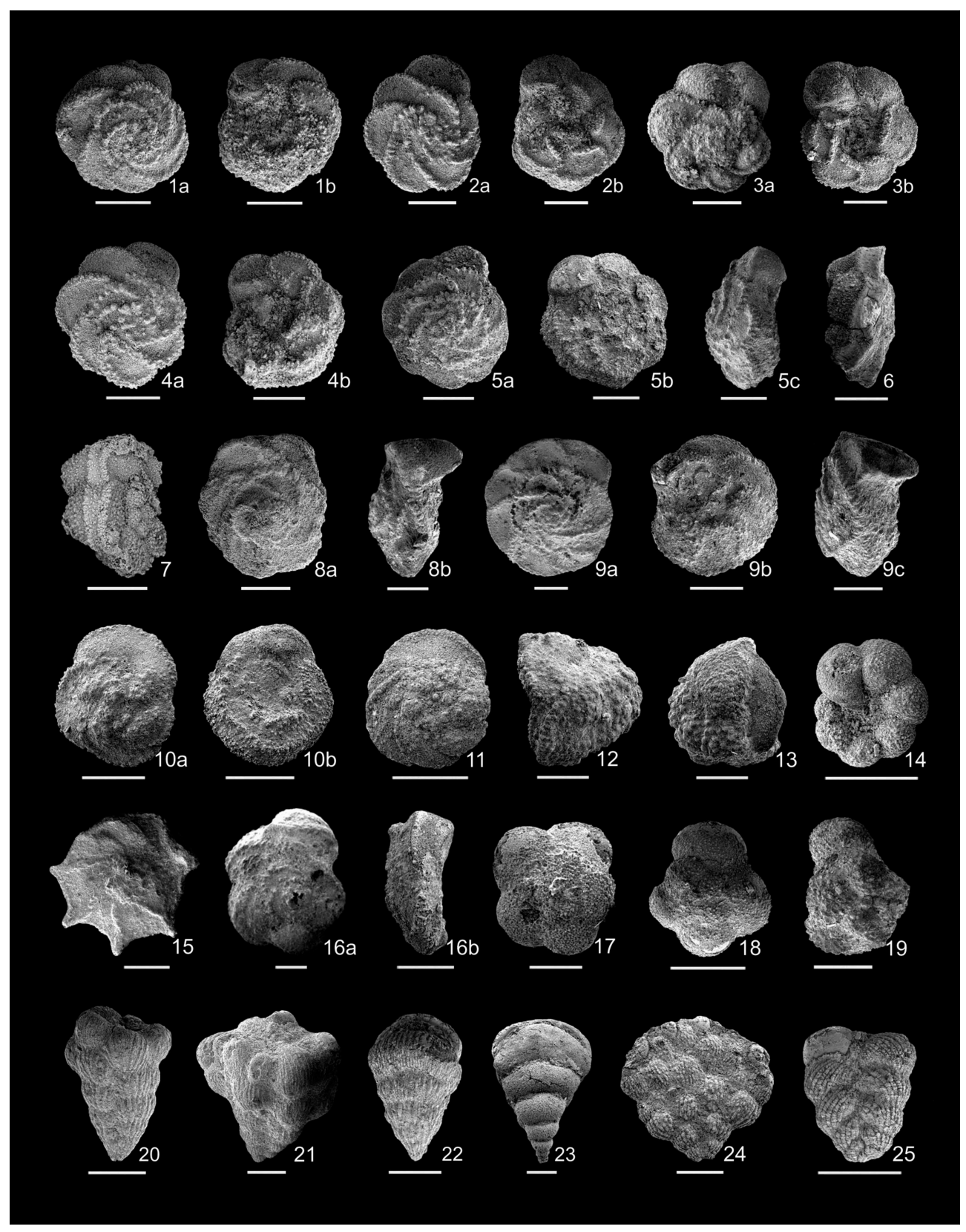

Figure 5. SEM photographs of the upper Santonian-Maastrichtian planktonic foraminifera from the Yenipazar (YP), İsmailler (IS), and Akdoğan (AK) sections, scale bars: $200 \mu \mathrm{m}$.

(1)Marginotruncana coronata (Bolli), YP-4, a-spiral view, b-umbilical view; (2) Marginotruncana pseudolinneiana Pessagno, YP-4, a-spiral view, b-umbilical view; (3) Marginotruncana marginata (Reuss), a- spiral view, b-umbilical view, YP-2; (4) Globotruncana linneiana (d'Orbigny), YP-3, a-spiral view, b-umbilical view; (5) Globotruncana arca (Cushman), IS-22, a-spiral view, b-umbilical view, c-side view; (6) Globotruncana ventricosa White, IS-18, side view; (7) Dicarinella asymetrica (Sigal), YP-7, oblique view; (8) Globotruncanita elevata (Brotzen), IS-3, a-spiral view, b-umbilical view, c-side view; (9) Globotruncanita stuarti (de Lapparent), IS-62, a-spiral view, b-umbilical view, c-side view; (10) Contusotruncana fornicata (Plummer), IS-62, a-spiral view, b-umbilical view; (11) Contusotruncana plummerae (Gandolfi), IS-31, spiral view; (12) Contusotruncana contusa (Cushman), IS-69, side view; (13) Contusotruncana walfischensis (Todd), IS-69, side view; (14) Globigerinelloides ultramicrus (Subbotina), YP-3, peripheral view; (15) Radotruncana calcarata (Cushman), IS-16, spiral view; (16) Abathomphalus mayaroensis (Bolli), a- IS-77, spiral view, b- IS-85, side view; (17) Globotruncanella havanensis (Voorwijk), IS-62, side spiral view; (18) Globotruncanella petaloidea (Gandolfi), IS-59, spiral view; (19) Kuglerina rotundata (Brönnimann), IS. 42, spiral view (20) Racemiguembelina powelli (Smith \& Pessagno), IS-77; (21). Racemiguembelina fructicosa (Egger), IS-77; (22) Pseudotextularia elegans (Rzehak), IS-57; (23) Pseudotextularia nuttalli (Voorwijk), IS-74; (24) Planoglobulina acervulinoides (Egger), IS-62; (25) Heterohelix semicostata Cushman, IS-30.

The Yenipazar Formation is overlain by the Kızılçay Formation along a prominent angular unconformity (Figure 4A). The basal sediments above the unconformity surface are made from angular boulders and gravels of tuff and marl derived from just beneath. Up-section, the unit is organised by alternating 
conglomerates, sandstones and caliche bearing mudstones as well as clayey limestones with an overall thinning-upward trend. Gravel imbrications and channel geometries indicate palaeocurrents towards the NW. In the uppermost part of the Kızılçay Formation, the Kabalar Member is well marked. It is made of a $90 \mathrm{~m}$ thick sequence of medium-to-thick bedded mollusca and charophyte bearing limestones, mudstones and bituminous shales. Based on the ostracoda fauna, a Lutetian age is assigned to the unit (Ocakoğlu et al. 2012). Spectral analysis of the unit pointed out $2.5 \mathrm{~m}$ thick precession cycles (Ocakoğlu et al. 2012). The Kızılçay Formation is conformably overlain by the mud-dominated shallow marine Güvenç Formation (Figure 4A). This unit consists of medium to thin bedded sandstone-mudstone alternations. Mudstones contain rich planktonic foraminifera fauna along with various bivalvia. This pelagic planktonic foraminifera fauna yields Acarinina bullbrooki (Bolli), Acarinina praetopilensis (Blow), Guembelitrioides nuttalli (Hamilton), Globigerinatheka subconglobata (Shutskaya), and Turborotalia frontosa (Subbotina), indicating a late Lutetian to early Bartonian age (Figure 6).

The Gemiciköy Formation gradually overlies the Güvenç Formation (Figure 4A). The lowermost $50 \mathrm{~m}$ is formed from mudstone and cross-bedded sandstone alternations. Following a coarsening upward trend, maximum clast size of components including gabbro, quartzite, radiolarite, basaltic lava, and lacustrine limestone reaches $25 \mathrm{~cm}$. Large basaltic lava and limestone blocks appear for the first time in the section.

\subsection{Taraklı section}

The Taraklı Section begins from the hinge of an anticline and extends to the subsequent synclinal axis in the vicinity of Taraklı (Figures 2 and 4B). This 1480 m-thick section comprises several formal units. The basal Yenipazar Formation formed from thin-to-medium bedded sandstone and mudstone alternations, which exhibits occasional slumps and Cretaceous limestone olistolites. Flute casts indicate NNE- and NE-directed palaeocurrents (Figure 4B \& SM Figure 2). Planktonic foraminifera biozones of Parasubbotina pseudobulloides and Praemurica uncinata indicate a late Danian age $(\sim 61 \mathrm{Ma})$ for the upper part of the unit. The Taraklı Formation gradually covers the Yenipazar Formation (Figure 4B). This unit comprises the alternation of fossiliferous medium to thick-bedded sandstones and mudstones. Some sandy intervals display large scale cross stratifications. The unit can be further subdivided into two distinct coarsening upward sequences between $180-220 \mathrm{~m}$ and $220-480 \mathrm{~m}$. In the lower part of the unit, we distinguished a planktonic foraminifera zone of
Morozovella angulata (early Selandian) (Figure 4B). Largescale cross bedding and groove casts indicate palaeocurrent directions heading to NW and NE. The KIzılçay Formation gradually overlies the Taraklı sandstones. It starts with sandstone and fine conglomerate alternations, and vertically evolves into thick $(4-5 \mathrm{~m})$ alternating conglomerates and thick red/green mudstones. Components of conglomerates are $4-5 \mathrm{~cm}$ and are derived from beige Cretaceous limestone, gabbro, radiolarite, and tuff. The Çataltepe Formation is composed of alternating fossiliferous sandstone, limestone, and mudstone, which transgressively overlies the Kızılçay Formation (Figure 4B). In this unit, sandstones are well-sorted and display symmetrical ripples. Thin coal and bituminous-smelling limestones are also present. Although richly fossiliferous, the unit did not yield any planktonic foraminifera. A rich ostracoda fauna including Cytherella sp., Hemiopprideis montoza, Neosyprideis cf., williamsonia indicates a probable early Eocene age. A gradual decrease in grain size gives rise to the Halidiye Formation. This unit is formed from the alternation of thick mudstone and turbiditic sandstone. Mudstone intervals are frequently composed of tiny mollusca and bivalvia shells, but are sparse in terms of planktonic foraminifera. Sandstones are thin $(<20 \mathrm{~cm}$, rarely $100 \mathrm{~cm}$ ), sharp-based and rich in plant debris. Ta and Tb Bouma sequences are the most common sedimentary structures. Asymmetrical ripples and flute casts indicate palaeocurrents from E to W (Figure 4B).

\subsection{Akdoğan section}

The Akdoğan Section starts close to the metamorphic basement of the CSB and continues until the synclinal axis in the south (Figure 4 C and SM Figure 3). The basal Değirmenözü Formation is composed of finely bedded pink mudstone and marl. Planktonic foraminifera, inoceramids, mm-sized bivalvia shells as well as Zoophycos trace fossils are abundant in the unit. An apparent gradual decrease in carbonate content and grey colour mark the boundary with the Yenipazar Formation. This unit is dominated by mudstones but includes three massive coarsening upward sandstone sequences (each several tens of metres thick and rich in bivalvia fauna). Very rarely, sharp-based, thin classical turbidite beds can also be found. Three planktonic foraminifera zones (Racemigumbelina fructicosa, Globanomalina pseudomenardii, and Morozovella velascoensis) have been distinguished, indicating a late Maastrichtian to early Ypresian age (Figures 4 and 6).

The Yenipazar Formation grades upward to the Halidiye Formation, which consists of turbiditic sandstone-mudstone alternations. Both lithologies are rich in plant debris. Sandstones are sharp-based, medium- 


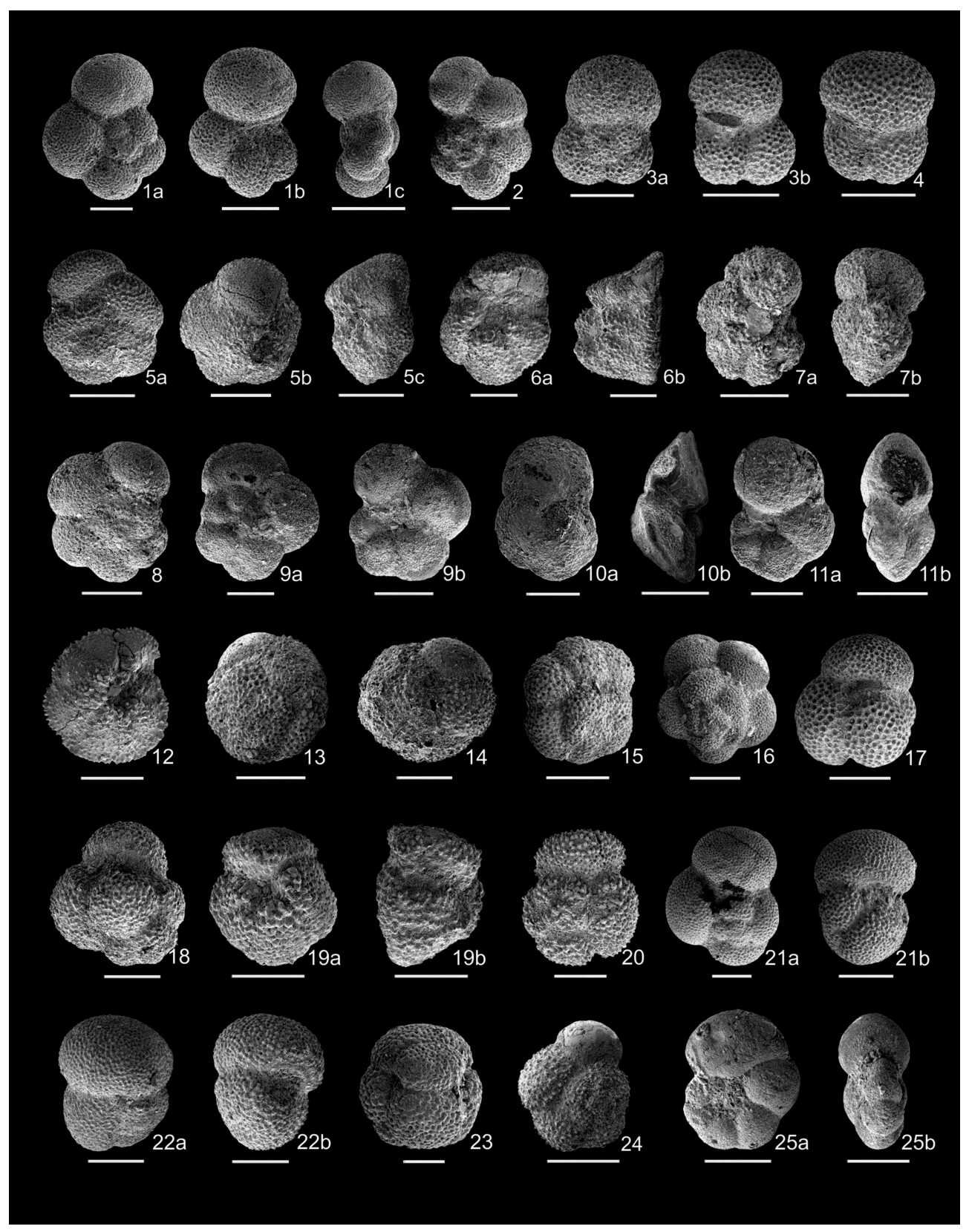

Figure 6. SEM photographs of the Palaeocene and middle Eocene planktonic foraminifera from the İsmailler (IS), Akdoğan (AK), Taraklı (TR), and Yenipazar (YP) sections, scale bars: $150 \mu \mathrm{m}$.

(1)Parasubbotina pseudobulloides (Plummer), IS-91, (a) spiral view, (b) umbilical view, (c) side view; (2) Praemurica pseudoinconstans (Blow), IS-91, spiral view; (3) Subbotina triloculinoides (Plummer), IS-91, (a) spiral view, (b) umbilical view; (4) Subbotina velascoensis (Cushman), AK-50, umbilical view; (5) Morozovella angulata (White), IS-96, (a) spiral view, (b) umbilical view, (c) side view; (6) Morozovella conicotruncata (Subbotina), (a) umbilical view, IS-94, (b) side view, IS-96; (7) Praemurica uncinata (Bolli), TR-11, (a) umbilical view, (b) side view; (8) Praemurica inconstans (Subbotina), IS-91, spiral view; (9) Globanomalina ehrenbergi (Bolli), IS-94, (a) spiral view, (b) umbilical view; (10) Globanomalina pseudomenardii (Bolli), (a) spiral view, AK-14, (b) side view, IS-95; 11. Globanomalina chapmani (Parr), (a) umbilical view, AK-14, (b) side view, IS-94; (12) Morozovella occlusa (Loeblich and Tappan), AK-14, umbilical view; (13) Acarinina nitida (Martin), AK-26, spiral view; (14) Acarinina subsphaerica (Subbotina), AK29, side view; (15) Igorina sp., YP-128, spiral view; (16) Eoglobigerina spiralis (Bolli), IS-91, spiral view; (17) Subbotina hornibrooki (Brönnimann), IS100, spiral view; (18) Guembelitrioides nuttalli (Hamilton), YP-128, side view; (19) Acarinina bullbrooki (Bolli), YP-128, (a) umbilical view, (b) side view; (20) Acarinina praetopilensis (Blow), YP-128, spiral view; (21) Subbotina eocaena (Gümbel), YP-130, (a) spiral view, (b) side view; (22) Turborotalia frontosa (Subbotina), YP-127, (a) spiral view, (b) side view; (23) Globigerinatheka subconglobata (Shutskaya), YP-128, side view; (24) Acarinina collactea (Finlay), YP-128, spiral view; (25) Pseudohastigerina micra (Cole), YP-128, (a) peripheral view, (b) side view.

to-thin bedded $(<1 \mathrm{~m})$ and are organized as 5- to 10-mthick lobes. Individual sandstone beds comprise mudchips, parallel laminations (Tb) and unidirectional ripples (Tc). Groove and flute casts coherently indicate palaeocurrents moving to NE and NW, and rarely $\mathrm{E}$ (Figure 4C). Following a thick covered interval, the section resumes with bluish marl-limestone alternations above the massive, non-fossiliferous sandstones. These 
micritic beige limestones with many ostracoda moulds and plant fragments closely resemble to the lithologies encountered in the Kabalar Member in the Yenipazar section.

\subsection{Nallıhan section}

The base of the Nallıhan Section starts with the $90-\mathrm{m}-$ thick pink-coloured Değirmenözü Member (Figure 7A and SM Figure 4). This unit consists of the alternation of slumped micritic limestones, marls and mudstones. The unit is rich in nannofossil, inoceramid, ostracoda and bivalvia. Some mudstone intervals also include coalified plant debris.

The overlying Yenipazar Formation consists mostly of grey-to-bluish coloured mudstones and thin turbiditic sandstones. The lower part of the unit comprises two m-thick black shale intervals (Figure 7A). Asymmetrical ripples and flute casts indicate palaeocurrents trending $\mathrm{N}$ and NNW. We distinguished the Eymür Member between levels 280 and $410 \mathrm{~m}$ in the Yenipazar Formation (Figure 7A), composed of gravelly sandstone, conglomerate and a lesser amount of mudstone. Sandstones comprise $\mathrm{cm}$-thick coalified plant debris. Conglomerates are mostly clast supported and include large $(>3 \mathrm{~m})$ angular boulders of Lower Cretaceous limestones beside medium sized, rounded gneiss and granite pebbles. The interbedded mudstones include rare planktonic foraminifera some of which are reworked from the Middle to Lower Cretaceous.

The red to grey to dark grey marl succession beneath the Eymür Member in this section is of early Campanian age based on the occurrence of the nannofossil marker species Marthasterites furcatus, Broinsonia parca constricta (CC18b, UC14b-c), Ceratolithoides verbeekii, Lithastrinus grillii (CC19, UC14d-15a). In the upper part of this section Ceratolithoides aculeus has its first occurrence which defines the base of CC20 and UC15b. The ca. 25-m-thick grey shale and marl interval below the first distinctive conglomerate bed of the Eymür Member yields a similar nannofossil assemblage with Ceratolithoides aculeus but, in addition, also includes the marker species that defines the next nannofossil zone with its first occurrence (FO), Uniplanarius sissinghii. The same assemblages and zonal markers were found in grey shales above the conglomerate unit along the section. This dates the conglomerates of the Eymür Member into the nannofossil zones CC21 and UC15c, respectively, which correspond to the base of the Upper Campanian (Burnett et al. 1998) or the upper part of the Middle Campanian of Ogg et al. (2012). According to the numerical age calibrations compiled by Anthonissen and Ogg (2012) this correlates to a time interval from $77.61 \mathrm{Ma}$ (base of Uniplanarius sissinghii) to $76.82 \mathrm{Ma}$ (base of Uniplanarius trifidus). A biostratigraphic study by Tansel (1980) previously considered the Eymür Member within the Radotruncana calcarata Zone. Following 100-m-thick marine mudstones, another sequence of turbiditic mudstone-sandstone alternations (15-20 m thick) is observed. Well-preserved flute casts indicate palaeocurrents towards the NE. Up section, a sandy intertongue within marine mudstones is remarkable at levels $780-800 \mathrm{~m}$. This interval typically coarsens upwards and comprises very large mollusca and echinoderm fossils including Pycnodonte vesicularis Lamarck and Micraster cf., cortestudinarium Goldfuss. Around $1000 \mathrm{~m}$ in to the section, planktonic foraminiferal fauna including Globotruncana arca, G. linneiana, Rugoglobigerina pennyi, Laeviheterohelix glabrans, Heterohelix globulosa, Globigerinelloides messinae, Pseudoguembelina sp., indicates late CampanianMaastrichtian age presumably very close to $\mathrm{K}-\mathrm{Pg}$ boundary. Conformably, the sample at level $1060 \mathrm{~m}$ comprises the planktonic foraminefera association that represents the Guembelitria cretacea-Parasubbotina pseudobulloides zones of the early Palaeocene (Figure 7A).

A gradual increase in grain size marks the passage to the Taraklı Formation at $1120 \mathrm{~m}$ (Figure 7A). This unit is formed from a dozen of massive sandy bodies over the mudstone-siltstone intervals. Sandstones are heavily bioturbated and host a rich mollusca fauna (Pycnodonte vesicularis Lamark, Turritella sp., Micraster cf., corangium Klein). The unit itself displays an overall coarsening upward trend, the top of which is formed from 7-8 cm gravel clasts sourced from the Cretaceous carbonates and basement gneiss.

Following the shoaling of the Taraklı Formation, deposition of thin $(<15 \mathrm{~cm})$ coal beds, cross bedded gravelly sandstone and caliche bearing red mudstone mark the onset of deposition of the Kızılçay Formation (Figure 7A). Coarse fluvial clastics include abundant reworked marine microfauna. The successive stratigraphic levels of the Kızılçay Formation are formed from the alternation of clast-supported conglomerate, sandstone and caliche bearing mudstones. Maximum clast size of the unit increases upward to $>25 \mathrm{~cm}$. Clast imbrications and cross-beddings mark palaeocurrents trending NNW and NE (Figure 7A).

\subsection{Okçular section}

The lowermost part of the Değirmenözü Formation is composed of pink to green mudstone-marl alternations (Figure 7B and SM Figure 5). Three distinct light blue tuff layers (4-10 $\mathrm{m}$ thick) also occur in this alternation. 
a Nallıhan Section

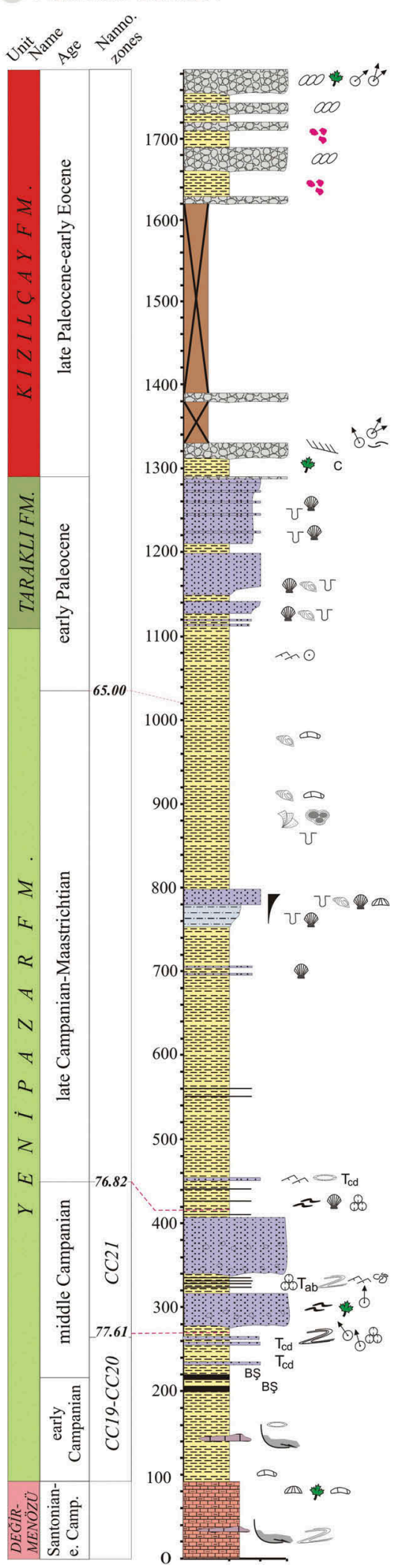

\section{b Okçular Section}
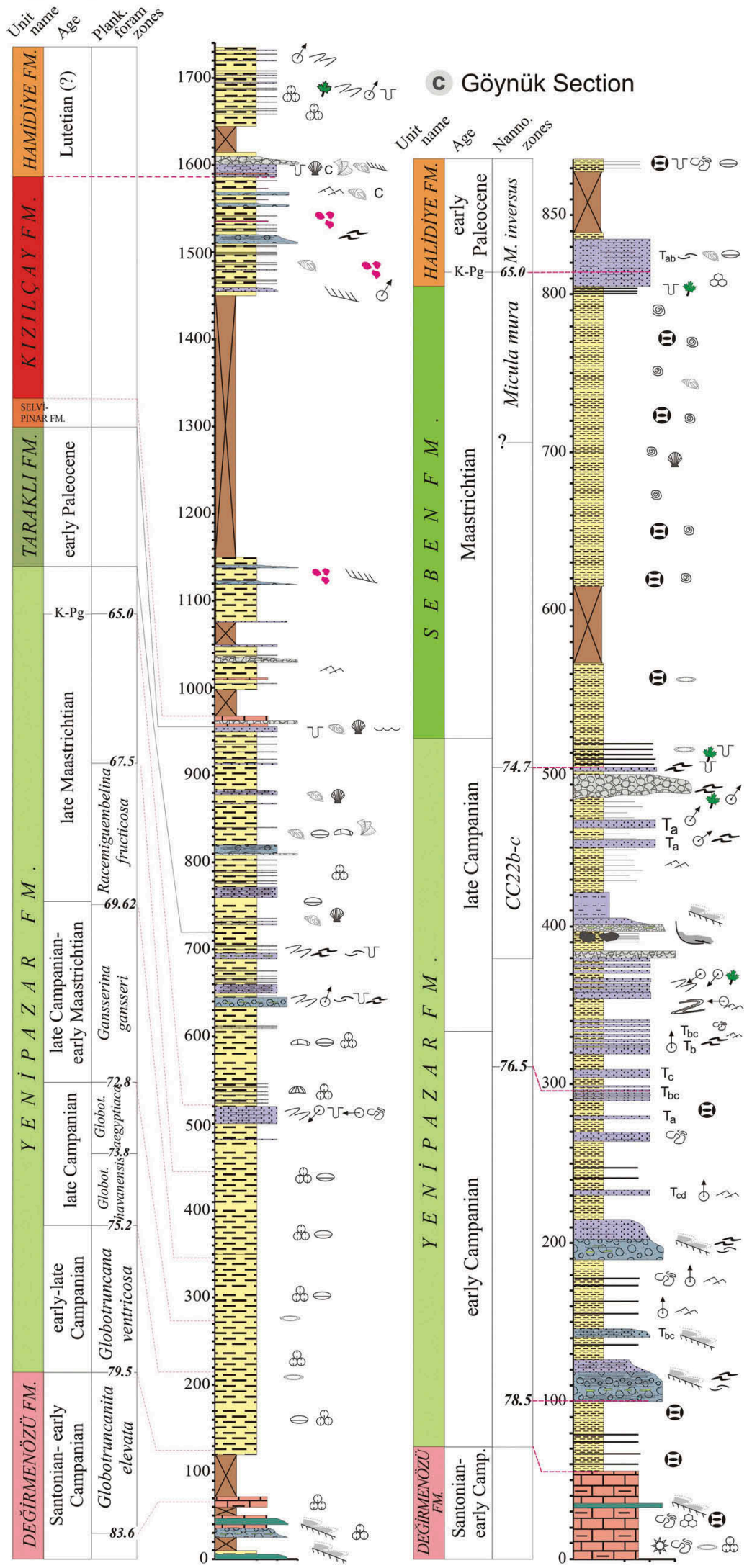

Figure 7. Detailed sedimentological logs of the Nallıhan (A), Okçular (B), and Göynük (C) Sections including biostratigraphic data (see Figure 2 for location, and Figure 9 for the legend). 
Tuff layers are finely laminated and contain lapilli-sized quartz and feldspar crystals as well as elongated marl/ tuff rip-ups up to $40-50 \mathrm{~cm}$. Just above the tuffs, we identified index fossils Globotruncanita elevata indicating an early Campanian age.

The transition to the Yenipazar Formation is gradual and marked by a change to more greyish colours and increase in carbonate content. The basal part of this unit $(120-500 \mathrm{~m})$ is entirely composed of mudstone where four planktonic foraminifera zones are distinguished (Figure 7B). Further up-section, turbiditic sandstone-mudstone alternations appear. Previous geochemical and biostratigraphical studies revealed that the K-Pg boundary is situated just above the first turbiditic sandstone sequence (Açıkalın et al. 2015) (Figure 7B). Individual horizons in this sequence are often thick-bedded $(\sim 130 \mathrm{~cm})$ and comprise Ta and Tb Bouma sequences, groove and flute casts, all indicating palaeocurrents heading to the $\mathrm{W}$ and NNW (Figure 7B). Interbedded mudstones have a rich microfauna of planktonic foraminifera (Eoglobigerina spp., Subbotina spp.,) benthic foraminifera, and ostracoda. The contact between the Yenipazar Formation and the overlying Taraklı Formation is placed over the grey-blue mudstone at $735 \mathrm{~m}$, where the first and abundant mollusca macro-fossils are encountered in this section. The Taraklı Formation is formed from thick mudstone and sandstone alternations. Mudstones include both micro-fossils (Globigerina sp., Subbotina sp., as planktonic foraminifera and undetermined benthic foraminifera) and macro-fossils (Ceratotrochus cuisine (coral), Cryaca uncifra and Barbatia subbarbatula (bivalvia)) collectively indicating a gross early Palaeocene age. Sandstone beds always include some cross-bedded gravel lenses with abundant macrofossils. The Taraklı Formation is conformably overlain by the Selvipınar Formation, a thin $(\sim 15 \mathrm{~m})$ unit of dominantly fossiliferous, partly detrital carbonate. The Kızılçay Formation conformably overlies the Selvipınar Formation (Figure 7B). This unit is made from thick $(>10 \mathrm{~m})$ redto-grey mudstone and thick (4-5 $\mathrm{m}$ ) channelized conglomerate/sandstone alternations. Mudstone intervals are frequently $30-$ to $40-\mathrm{cm}$-thick caliche beds. In two different stratigraphic levels (1484 m and $1572 \mathrm{~m}$ ), we encountered lacustrine limestones with gastropod shells. Components of conglomerates are well rounded, and are mostly composed of quartzite, gabbro, radiolarite and intraformational mudstones. Widespread planar and trough-cross bedding in overlying sandstones indicate NE-directed palaeocurrents (Figure 7B).

$A$ fining-upward marine sequence (Halidiye Formation) transgressively overlies the terrestrial Kızılçay Formation (Figure 7B). The lower, sandstone- gravely sandstone alternation in this unit displays a series of diagnostic features (well rounded and sorted clasts, occurrence of coal seams etc.) of a littoral zone, and comprises a rich benthonic fauna including bivalvia, gastropoda, and solitary corals. The overlying 100$\mathrm{m}$-thick fine-grained interval is composed of thin $(<60 \mathrm{~cm})$ sandstone and mudstone alternations with a planktonic foraminifera fauna (Morozovella spp., Acarinina spp.,) of poor biostratigraphic significance.

\subsection{Göynük section}

The Değirmenözü Formation in the Göynük area is up to $170 \mathrm{~m}$ thick, of which only the uppermost $55 \mathrm{~m}$ is displayed in our section (Figure $7 C$ and SM Figure 6). Thin $(5-10 \mathrm{~cm})$ micritic limestone beds alternate with mm-thick red mudstones. Both lithologies include rich fauna of planktonic foraminifera, nannofossils, radiolarians and inoceramids. Radiolarian fauna give a rather wide time span of late Turonian-early Campanian (determined by U.K. Tekin, Hacettepe University). Three yellow tuff layers up to $2 \mathrm{~m}$ thick are interleaved in the section. A recent study by Wolfgring et al. (2017) indicated that the unit encompasses the SantonianCampanian transition and mostly spans early Campanian at the uppermost levels with 5.2-m-thick eccentricity cycles (400 ka). Similar to previous sections, passage to the Yenipazar Formation is demarcated by a decrease in carbonate content and a change to greyer colours. This unit is formed from the alternation of thick tuff and siliciclastic intervals (Figure 7C). Three tuff levels at $100 \mathrm{~m}, 140 \mathrm{~m}$, and $200 \mathrm{~m}$ are cumulatively $25 \mathrm{~m}$ thick. Each tuff bed is typically sharp-based, thins upward, and comprises $\mathrm{dm}$ - to $\mathrm{m}$-sized rip-up clasts and shell fragments in a sand-sized quartz and feldspar background. Groove and flute casts are common. The siliciclastic part of the unit consists of thick grey mudstone and thin $(<15-20 \mathrm{~cm})$ turbidite sandstones. Sandstones frequently display Tb, Tc-d Bouma sequences and unidirectional ripples that indicate palaeocurrents heading to $\mathrm{N}$ and NE (Figure 7C). Several thick channelized conglomeratic levels (3$10 \mathrm{~m}$ thick) with well-rounded clasts up to $20 \mathrm{~cm}$ also interleave with finer clastics. Gravels are mostly derived from radiolarite, beige Lower Cretaceous carbonate and intraformational mudstone and sandstone. Around $390 \mathrm{~m}$ in to the section, huge (several ten to hundred $\mathrm{m}$-sized) olistostromes and broken formations are observed in two distinct stratigraphic levels (Figure 8). Out of place bodies belong either to Lower Cretaceous pelagic limestones or newly deposited calcareous mudstones. Slickenlines indicate displacement towards the NNW. Two U-Pb ages from zircons are recovered in the 


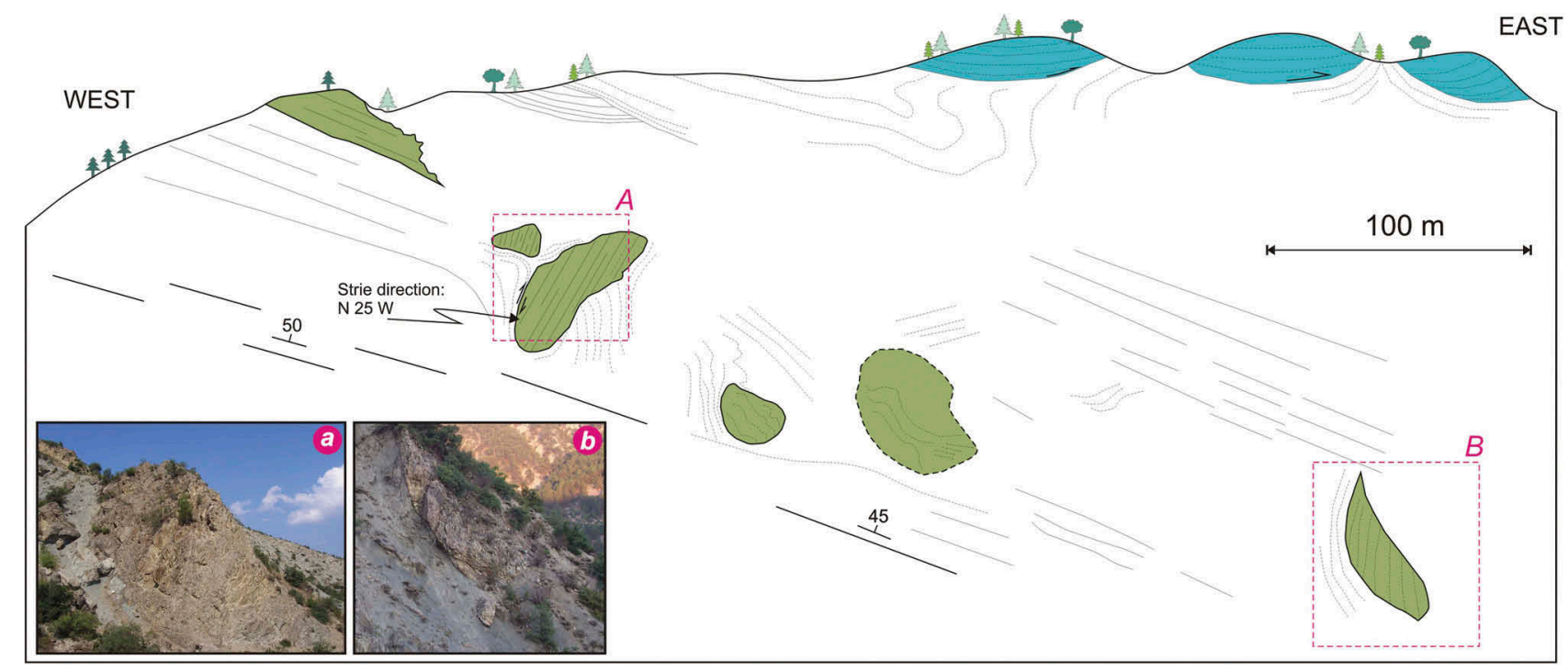

Figure 8. Widespread slumps in the Middle-Late Campanian sediments, $500 \mathrm{~m}$ east of the Göynük town. Subfigures display a penecontemporaneous marl block with well-preserved slickensides over the mudstone matrix (A), and a recrystallized Cretaceous limestone block in the shale matrix (B).

unit. The first tuff level at $100 \mathrm{~m}$ in this section (Figure 7C) yielded an age of $78.5 \pm 1.6 \mathrm{Ma}$ based on $n=91$ zircons (early Campanian) (Supplementary Table 1). A sandstone bed just beneath the uppermost thick conglomerate at $480 \mathrm{~m}$ gives a maximum deposition age of $76.4 \pm 1.7 \mathrm{Ma}$ based on $n=19$ zircons, and established that the majority of zircons are detrital in origin (see Supplementary Table 1).

Samples from grey shale below the conglomerate at level $480 \mathrm{~m}$ of the section yield nannofossil assemblages including Uniplanarius trifidus, which defines the base of biozones CC22 and UC15d. Other markers such as Ceratolithoides aculeus and Broinsonia parca constricta are also observed. The absence of Lithastrinus grillii (last occurrence of which defines the top of biozone CC22a and the lower part of UC15dTP), the continuous presence of Eiffellithus eximius and Reinhardtites anthophorus, and the presence of transitional forms from Reinhardtites anthophorus to Reinhardtites levis (which define the base of CC22c) indicate that this unit belongs to the upper part of biozone CC22 (CC22b-c of Perch-Nielsen 1985) and UC15dTP, below the last occurrence of both Eiffellithus eximius and Reinhardtites anthophorus. According to these results, the conglomeratic interval at Göynük can be assigned to nannofossil zones CC22b-c and UC15d-eTP, indicating a late Campanian age (Figure 7C).

The Seben Formation gradually overlies the Yenipazar Formation and consists entirely of grey mudstones with abundant nannofossil, bivalvia and gastropoda. Here, the Halidiye Formation is particularly sandy and gradually overlies the Seben Formation (Figure 7C). This unit is a coarsening upward package of sharpbased sandstone and mudstone alternations. Individual sandstone beds are normally graded and have groove casts and trace fossils including Ophiomorpha rudis, Scoliacia strozzii, and Palaeodiction majus, all of which indicate deposition in a deep marine environment. The K-Pg boundary is determined to be close to the base of the Halidiye Formation based on the passage from the nannofossil biozone of Micula murusa to Markalius inversus at the $815 \mathrm{~m}$ level of the section (Figure 7C).

\subsection{Ismailler section}

The İsmailler Section represents the pelagic/hemipelagic deposition in the deeper, northern part of the basin and belongs almost entirely to the Yenipazar Formation except the lowermost and uppermost parts (Figure $9 \&$ SM Figure 7). The Değirmenözü Formation is thicker here and is as old as the Upper Santonian (Yılmaz 2008). Our section begins from the uppermost $30 \mathrm{~m}$ of this unit which is composed of alternation of thin $(<10 \mathrm{~cm})$ pink marls and mudstones. Meter-sized slumps are common in the unit. The top of the Globotruncana elevata Zone is situated very close to the upper contact of the unit (Figures 5 and 9). The overlying Yenipazar Formation is almost fully composed of mudstones extremely rich in planktonic foraminifera. Eleven planktonic foraminifera zones are distinguished in the unit (Figures $5 \& 9$ ). The lowermost part of the Yenipazar Formation comprises a 15-m-thick package of 


\section{7 İsmailler Section}

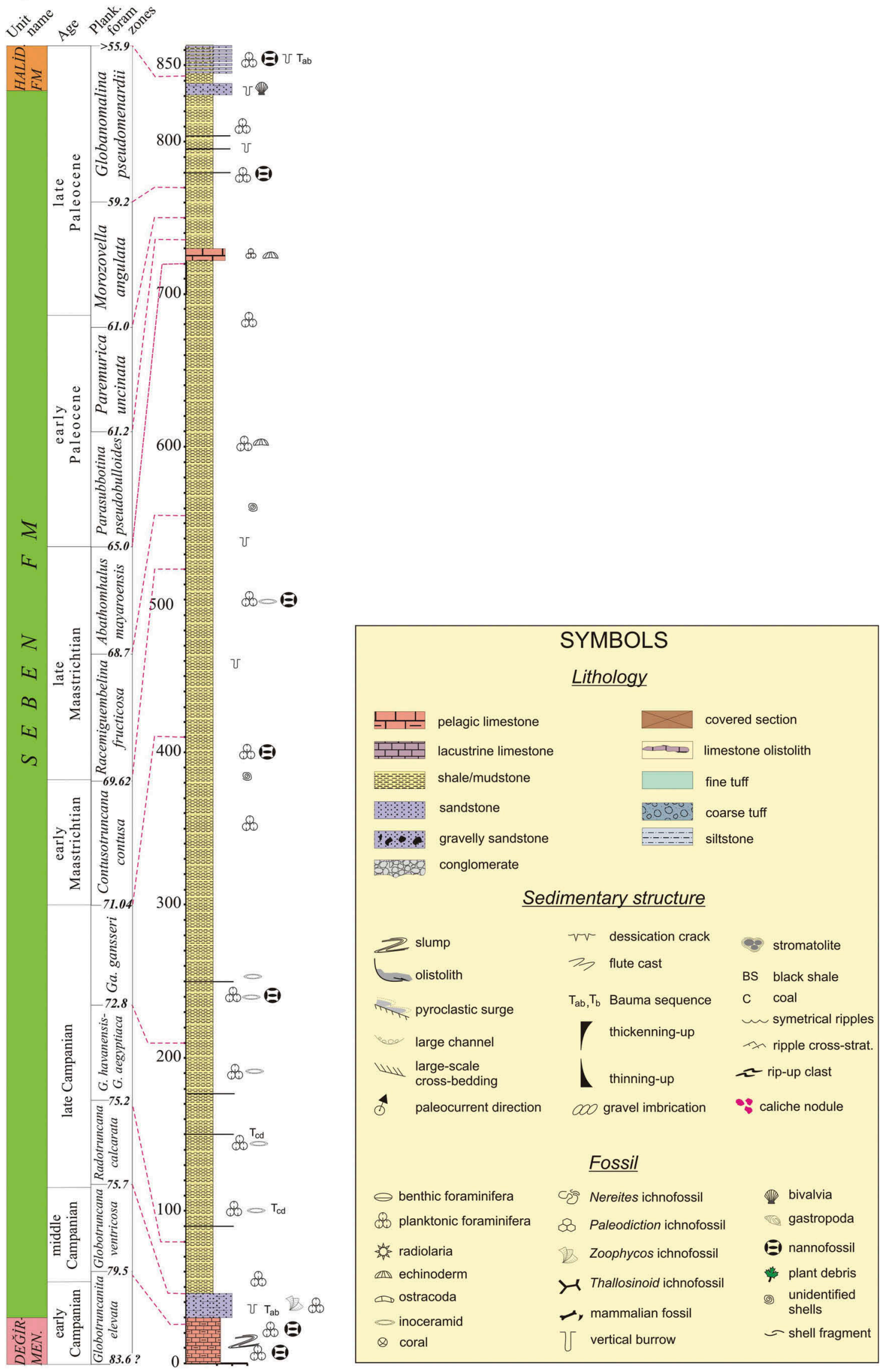

Figure 9. Detailed sedimentological log of the İsmailler Section including biostratigraphic data (see Figure 2 for location). 
gradual passages to fine sandstone-marl alternations. Sandstones exhibit parallel laminations and are intensively bioturbated locally by Echinospira trace fossils. This sandy interval is entirely restricted to the Globotruncana ventricosa Zone (Figure 5). Following a very thick mudstone succession, a carbonate interval is seen just above the K-Pg boundary (Figure 9). This $15 \mathrm{~m}$-thick thin marl-limestone alternations is strikingly similar to the contemporaneous part of the Okçular section $40 \mathrm{~km}$ to the SE. Following another thick interval of mudstones, sharp-based medium-to-thick beds of the Halidiye Formation appear at the top of the section. Interbedded mudstones include planktonic foraminifera, nannofossil and ostracoda fossils. The Halidiye Formation is confined to the uppermost part of the Globanomalina pseudomenardii Zone ( $55.9 \mathrm{Ma})$ (Figures 6 and 9).

\section{Basin-fill architecture}

Here, the measured sections are assembled in order to build two SE-NW bearing geotraverses on the basis of their geographic positions in the basin (Figures 10 \& 11). In order to aid comprehension regarding the timing of sedimentary events, we have also constructed temporal geotraverses (Figure 12) based on the linear extrapolation of the available biozone age data. These nonpalinspastic reconstructions are based on the correlation of depositional environments in the adjoining sections tied by planktonic foraminifera and nannofossil biozones, as well as U-Pb age data. Numerical ages of planktonic foraminiferal zones are compiled from Robaszynski and Caron (1995), Berggren et al. (1995), Berggren and Pearson (2005), Petrizzo et al. (2011), Wade et al. (2011), Gradstein201616, and Coccioni and Silva (2015). We have also calculated sedimentation rates with time based on the thickness of sediments deposited during the individual planktonic foraminiferal zones in different measured sections (Figure 13).

The Yenipazar geotraverse exhibits a $1 \mathrm{~km}$-thick flyschoidal succession (Yenipazar Formation) beneath an early late Palaeocene $(\sim 61 \mathrm{Ma})$ angular unconformity (Figure 10). Absolute ages of planktonic foraminifera zones allow us to calculate an overall relatively low sedimentation rate $(2.8 \mathrm{~cm} / \mathrm{kyr})$, which prevailed during the early Campanian (83.5-79.6 Ma) in a deep marine pelagic carbonate setting. Evidence for repeated slumps in the Değirmenözü Member and palaeocurrent data indicate that the inner, deep parts of the basin were fed by the erosion/dismantlement of a carbonate system located at the southern margin of the basin. Flyschoidal deposition replaced this environment right at the upper limit of the Globotruncanita elevata Zone in mid-Campanian (79.6 Ma). Soon after, products of a submarine explosive volcanism start to alternate with

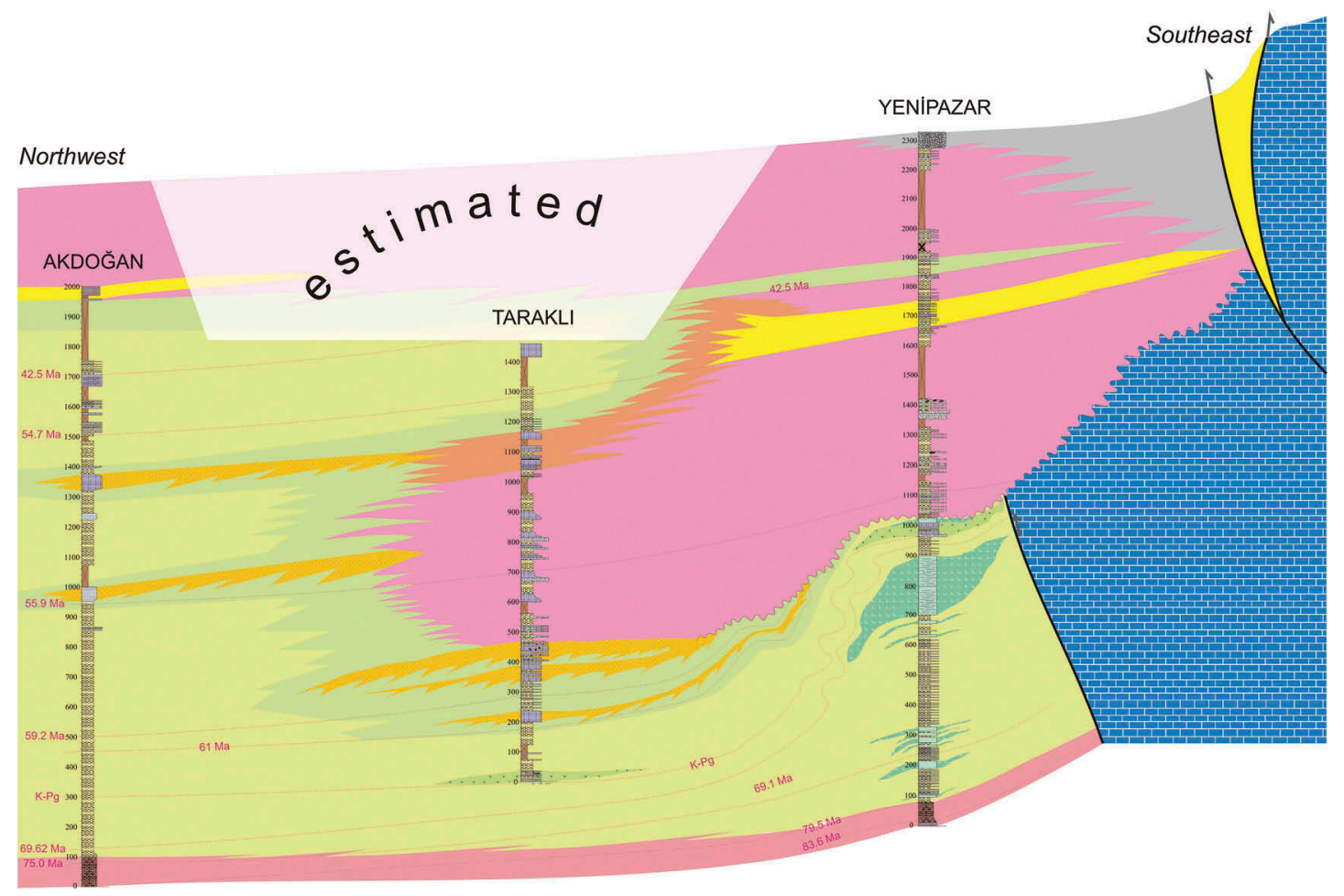

Figure 10. Yenipazar geotraverse (see Figure 2 for the location of the sedimentological logs). 
siliciclastic sediments until $900 \mathrm{~m}$ in to the section. This huge volume of pyroclastic material may have been sourced from a volcanic centre $10 \mathrm{~km}$ west of Yenipazar town, whose subsurface igneous counterparts were mapped by Gedik and Aksay (2002) (Figure 2).

According to the Yenipazar geotraverse, the lateral equivalent of the unconformity surface in the northerly Taraklı section is the $200 \mathrm{~m}$ thick sandy Taraklı Formation and not the Kızılçay Formation (Figure 10). The rationale behind this correlation is the gradual passage from basinal sediments to deltaic sandstones of the Taraklı Formation in the northern portions of the basin, compared to direct terrestrial sedimentation on the unconformity surface in the southern areas (Figure 10). Validation of this correlation hinges on being able to date the base of the Kızılçay Formation in the Yenipazar Section - however, internal coherence of the scaled Yenipazar geotraverse strongly suggests that this correlation is correct.

The very base of the deltaic Taraklı Formation starts extremely close to the base of the Morozovella angulata biozone $(\sim 61 \mathrm{Ma})$ when the sedimentation rate was extremely high (12-42 cm/kyr) (Figure 13). Above the unconformity surface, the Kızılçay Formation occupies the central and northern areas and grades northward to massive mudstones of the Yenipazar Formation. Two progradational delta-front sandy tongues were observed in the Akdoğan section at levels $1000 \mathrm{~m}$ and $1350 \mathrm{~m}$, which according to our biozone data likely correspond to the early Thanetian $(\sim 55.9 \mathrm{Ma})$ and late Thanetian $(\sim 55 \mathrm{Ma})$ respectively.

After these two episodes of deltaic progradation, a marine transgression occurs in Ypresian times (Figure 10). The correlative of this transgression in the southern Yenipazar area is the lagoonal Kabalar Member. Almost contemporaneously, a deep marine turbidite system initiated in the northern Taraklı and Akdoğan sections. Dominant E-W palaeocurrent directions imply an uplifted area north of the basin. The marine Halidiye Formation marks the final, and shortlived transgression in the basin during late Lutetian times reaching as far south as the town of Yenipazar. This major maximum flooding surface of late middle Eocene age can be correlated with other marine units along the suture zone (Licht et al. 2017) and potentially corresponds to the $40.4 \mathrm{Ma}$ flooding surface in the global sea level chart of Hardenbol et al. (1998). The terrestrial Gemiciköy Formation progradationally overlies marine units and is composed of abundant basaltic lava as well as reworked lagoonal carbonate gravels from the Kabalar Member, indicating the onset of a basaltic volcanism and on-going tectonic uplift in the south (Figure 10).

The Nallıhan geotraverse displays a similar sedimentary history but omits the last 10 Myr of the Yenipazar geotraverse (Figure 11). In this geotraverse, pelagic carbonate deposition with frequent slumps developed before shifting to flyschoidal deposition at $~ 79.6 \mathrm{Ma}$. The sedimentation rate during carbonate deposition and just afterward was very low (0.5$0.6 \mathrm{~cm} / \mathrm{kyr}$ ) (Figure 13). A smaller submarine volcano erupted several tuff beds just before the Globotruncanita elevata Zone $(\sim 83.5 \mathrm{Ma})$ in the Göynük and Okçular section (Figure 11). About 1 Myr following the onset of flysch deposition, another submarine volcano, this time more voluminous, resumed in the Göynük section at $\sim 78.7 \mathrm{Ma}$. After ejecting several very thick tuff intervals in vicinity of Göynük, volcanism ceased around $76 \mathrm{Ma}$ as demonstrated by our younger zircon age and biostratigraphic data from the nearby Karaardıç section (Ocakoğlu et al. 2007).

The Nallıhan geotraverse also sheds light upon the stratigraphic position of the coarse clastic wedges (Eymür Member) in the Yenipazar Formation (Figure 11). The first siliciclastic wedge is confined within the CC21 nannofossil zone in the Nallıhan section and would be correlated with the Cam 6 major sequence boundary (77.8 Ma) of Hardenbol et al. (1998). The second deep marine clastic wedge is recognized and dated to $75.9 \mathrm{Ma}$ in the Göynük section and can be correlated to the Nallıhan section. A third siliciclastic wedge is observed just beneath the K-Pg boundary in the Göynük and Okçular sections (Figure 11) and may be correlated with the Ma5 sequence boundary (65.42 Ma) of Hardenbol et al. (1998). The final deep marine siliciclastic wedge is observed in the uppermost part of the Ismailler section around the middle Ypresian $(\sim 55 \mathrm{Ma})$ and can also be correlated with Hardenbol et al. (1998).

In the late Maastrichtian and early Palaeocene, the Nallıhan area seems to have been in a shelf position as evidenced by the fossiliferous mudstone and deltaic progradation at level $750 \mathrm{~m}$ in contrast to the rest of the basin (Figure 11). Deltaic deposition of the Taraklı Formation began on the order of several hundred metres above the K-Pg boundary probably during the late Palaeocene in both the Nallıhan and Okçular sections in agreement with the well-dated Taraklı Section.

The Kızılçay Formation in the Nallıhan geotraverse is about $650 \mathrm{~m}$ thick and exhibits a lateral grain size decrease and facies changes from the Nallıhan to 


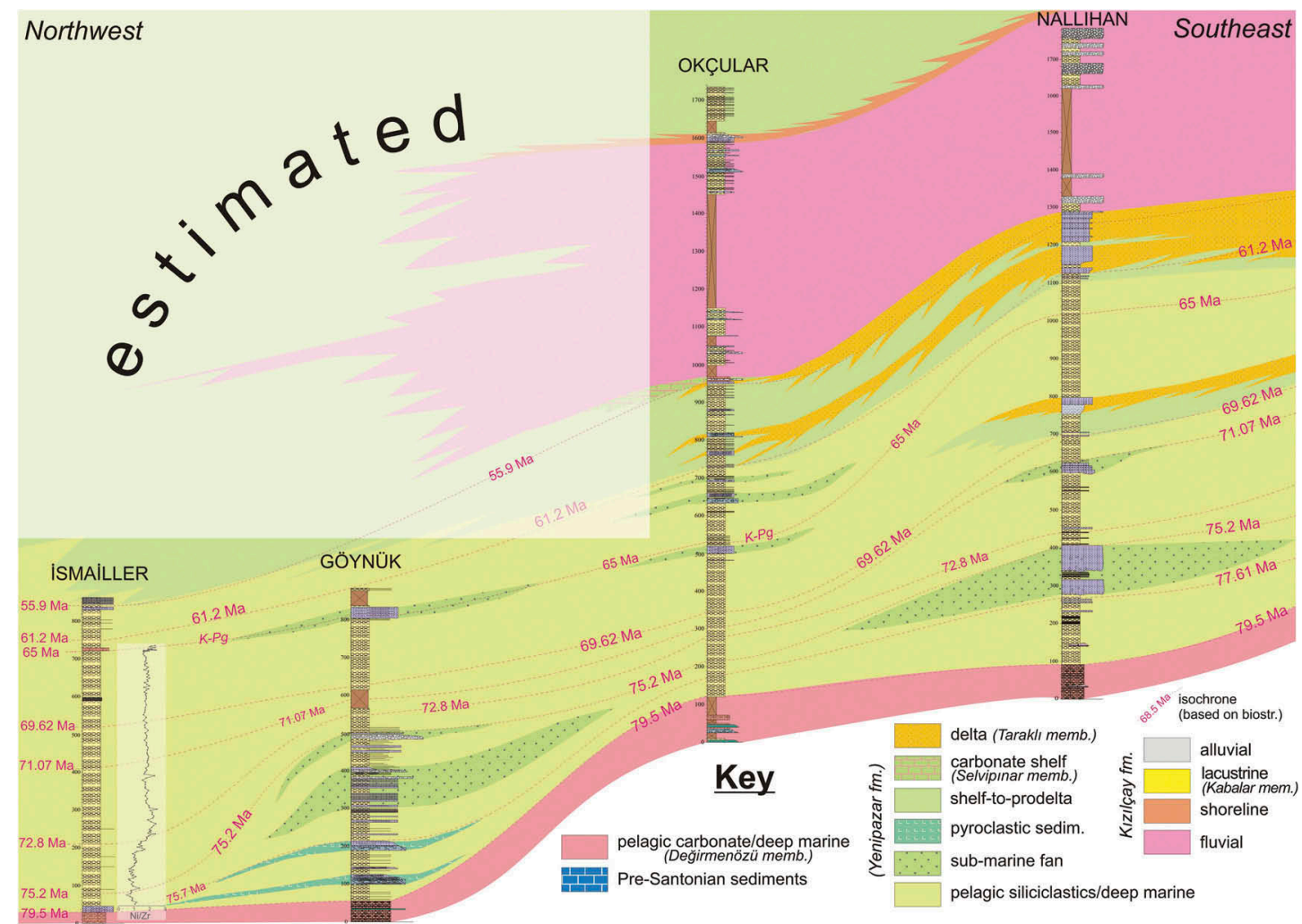

Figure 11. Nallıhan geotraverse (see Figure 2 for the location of sedimentological logs).

Okçular sections (Figure 11). The transgressive Çataltepe Formation which is only preserved in the Okçular section is Ypresian (probably latest Ypresian) in age as indicated by macrofossil fauna. The youngest sedimentary record in this geotraverse is the deeper shelf fine sediments of the Güvenç Formation of late Lutetian-early Bartonian age.

\section{Discussion}

\subsection{Tectonic vergence and basin morphology}

During the Turonian-early Campanian period, the CSB was dominated by pelagic carbonate deposition (Değirmenözü Member) without significant (if any) sub-areal exposure at its margins that would have sourced siliciclastic influx (Figure 12A, B; Figure 14A). Plurimetric reversed and recumbent slumps observed in the southerly Yenipazar and Nallıhan sections seem to have developed on north dipping slopes of the basins southern margin (Figures 10 and 11). Meter-sized olistoliths in the Nallıhan section imply active deformation along the southern margin. We thus suggest that during the Turonian-early Campanian times, incipient uplift along the southern margin of the basin was already occurring. It is however only after 79.5 Ma that the siliciclastic influx derived from the uplifted sub-aerially exposed areas started to choke carbonate deposition, gradually giving rise to siliciclastic sedimentation (Figure 14B). This is well expressed in the rising sedimentation rates in the Okçular and İsmailler sections especially after $\sim 76 \mathrm{Ma}$ (Figure 13). At almost the same time, the carbonate deposition in the Haymana Basin, which was developed as an accretionary forearc basin along the southern active margin of the Pontides, was also replaced by siliciclastic deposition, driven by tilting, folding and uplift along the accretionary prism (Okay and Altıner 2016).

Our palaeocurrent data from the Yenipazar and Seben Formations show that throughout the Campanian and Maastrichtian, sediment influx was dominantly supplied from the southern margin of the basin, where the accretionary prism of the northwarddipping subduction zone was being built. Somewhat different palaeocurrent directions with a dominant E-W component are attributed to local bathymetric anomalies induced by submarine volcanism. In the İsmailler section, Ocakoğlu et al. (2007) and Açıkalın et al. (2016) show a significant increase in the elemental rate of $\mathrm{Ni} /$ $\mathrm{Zr}$ starting at $185 \mathrm{~m}$ around $\sim 73 \mathrm{Ma}$ (Figure 11). This rise in the $\mathrm{Ni} / \mathrm{Zr}$ ratio continues for $\sim 1.4 \mathrm{Myr}$ until $260 \mathrm{~m}$ in to the section, and then remained constant for the rest of the basin-fill. Açıkalın et al. (2016) concluded that this increase would correspond to the sub- 

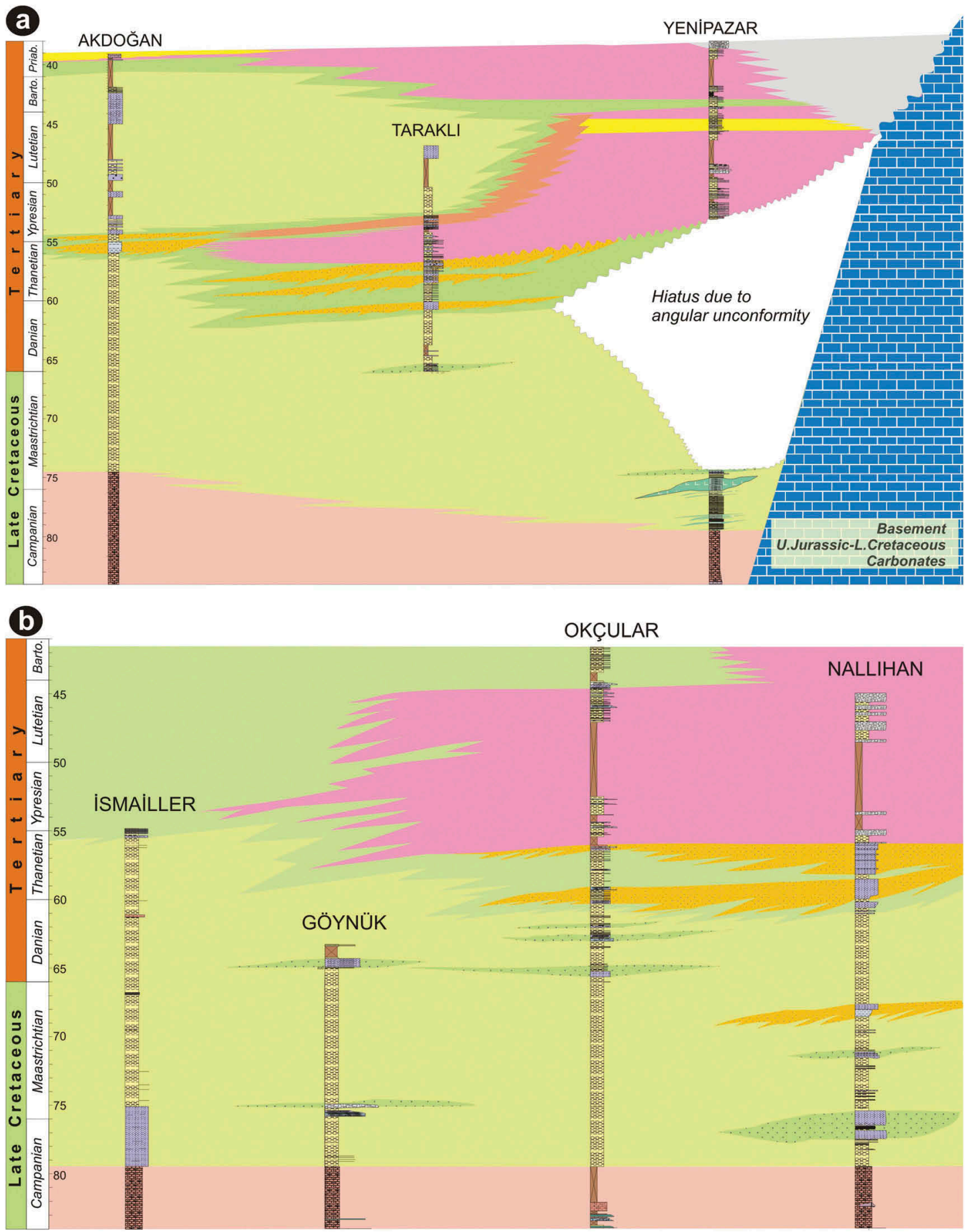

Figure 12. Temporal geotraverses along the Central Sakarya Basin. A- Yenipazar temporal geotraverse B-Nallıhan temporal geotraverse.

aerial expansion of subduction-related accretionary prism with ultramafic slices (Figure 14B). During this period, sedimentation rates were extremely high (11$12 \mathrm{~cm} / \mathrm{kyr}$ ) in the İsmailler section (Figure 13). However, it is surprising to see that this anomaly does not match with the major submarine fan development in the Göynük and Nallıhan areas (Figure 11).
A massive progradation across the Palaeocene and Eocene was previously suggested in the CSB by Saner 1977, Saner (1980). Both our basin-wide geotraverses refine the suggested timing of events proposed by these early works. Apparent progradation started around $\sim 61 \mathrm{Ma}$ over the marine shales and is clearly expressed by the extremely high sedimentation rates 


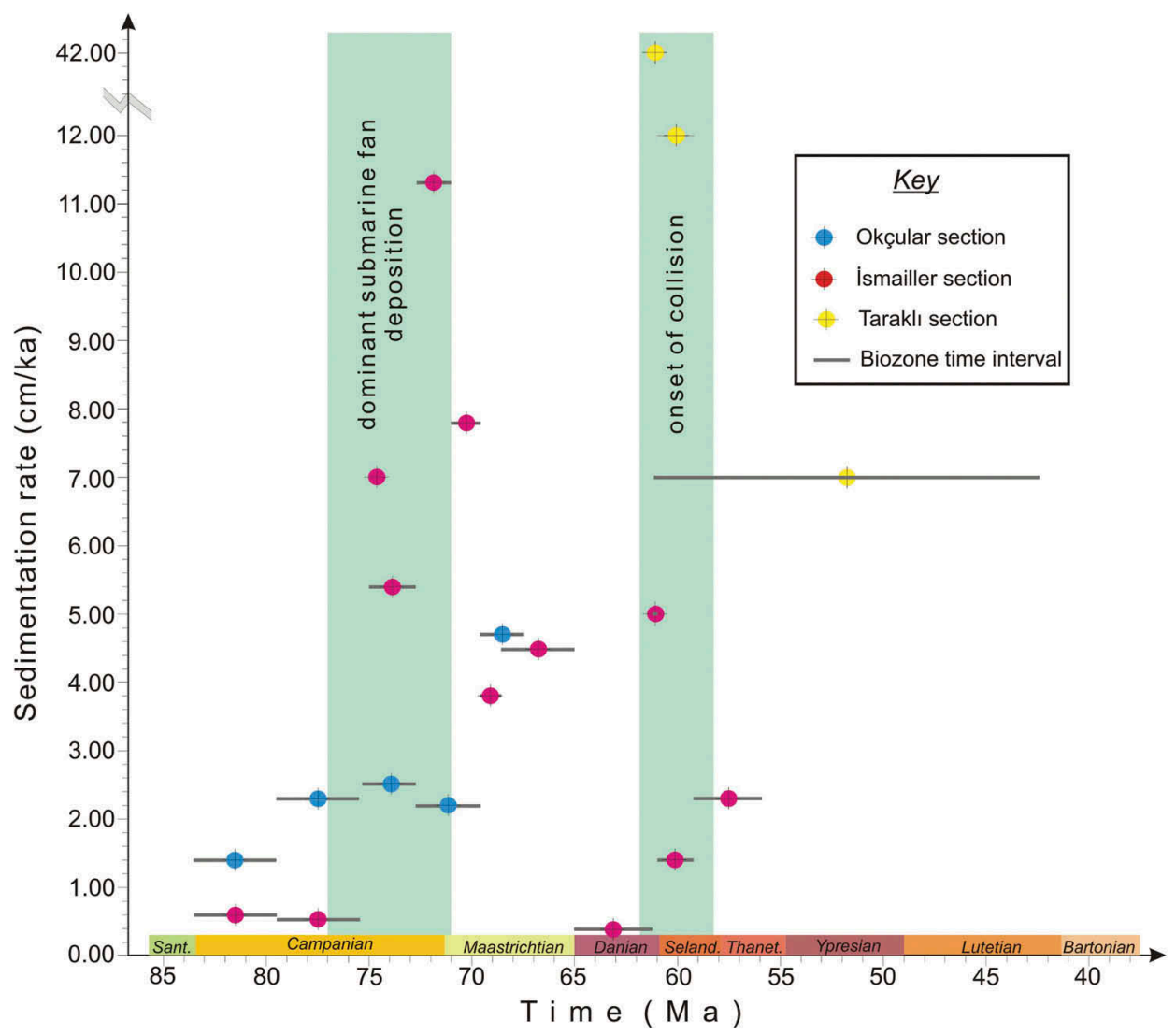

Figure 13. Sedimentation rates with time based on the planktonic foraminifera biozones in three measured sections in the Central Sakarya Basin (see Figure 2 for the location of the sections).

(12-42 cm/kyr) in the Taraklı Section (Figures 12A and 13). During the same period, varying but reduced sedimentation rates were documented in the more basinal İsmailler section, probably due to high frequency relative sea level changes that would have radically shifted the depocentre with time (Figure 13). Sub-aerial depositional environments expanded northward from the accretionary prism to the towns of Taraklı and Göynük in the Thanetian with two exceptional deltaic progradations during the early and late Thanetian (Figure 10, 11, 12A, B \& 13C). The last and the most extensive progradation occurred at $\sim 47 \mathrm{Ma}$, shortly after the late Lutetian transgression. Facies and palaeocurrent data indicate an elongated E-W trough between the towns of Taraklı and Akdoğan in the Lutetian. Our palaeogeographic reconstructions match well with the results of Özcan et al. (2012) between Kocaeli and the Black Sea coasts in the Pontide Zone, north of our study area. These authors described turbidites in the SantonianCampanian whilst a volcanic/volcanoclastic succession forms further north. Even if we assume their turbidites as the distal correlatives of the NallıhanGöynük turbidites, they could also be sourced from the Campanian magmatic arc situated further north along the Black Sea Mountains.

\subsection{Santonian-Campanian arc volcanism}

Our results indicate two temporally distinct episodes of volcanism whose products have different thickness and facies intercalated in the Santonian-Campanian sedimentary units. The first is characterized by relatively thin $(<3 \mathrm{~m})$ vitric-to-crystal tuff interbedded within the micritic limestone-mudstone alternations (Ocakoğlu et al. 2007). Typical products of this volcanism are encountered only in vicinity of Göynük (Göynük, Okçular and Sünnet sections). In the Okçular section, the position of the tuffs are 20-30 m below the lower limit of Globotruncanita elevata Zone ( $83.5 \mathrm{Ma})$ and within the Dicarinella asymetrica Zone in the Sünnet section. Considering the position of the tuff levels with respect to biozone limits, it seems reasonable to attribute 84.4 Ma for this short-term volcanism.

The second episode of volcanism was more extensive and long-lived compared to the former. Products of this volcanism are composed of grey to green crystal tuffs and found as intercalations in the siliciclastic 


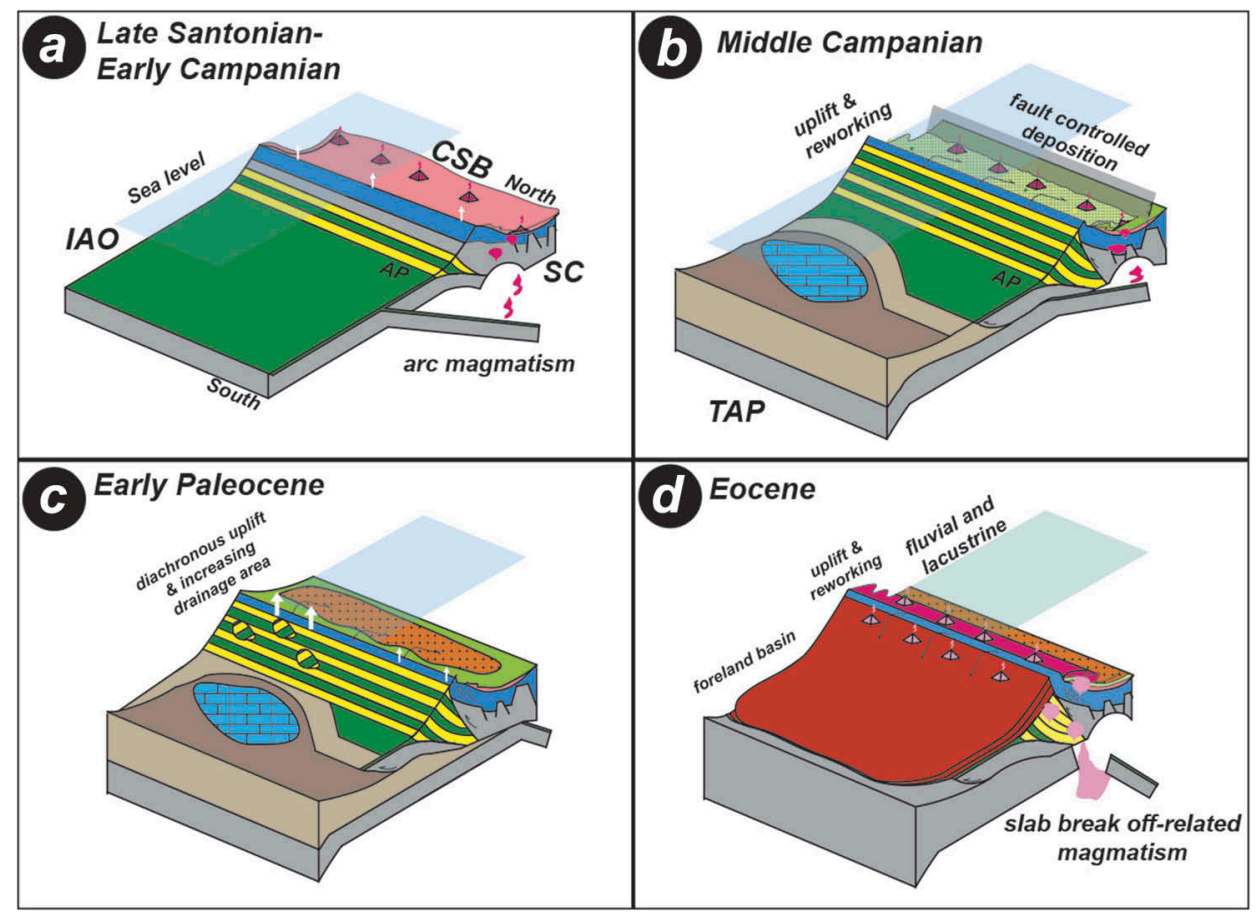

Figure 14. Sketches depicting the plate tectonic evolution of the Central Sakarya Basin across late Santonian-Eocene. (a) Late Santonian-early Campanian: pelagic carbonate sedimentation and coeval arc volcanism related to an intra-oceanic subduction. (b) Middle Campanian: uplift of accretionary prism and onset of turbidite deposition. (c) early Palaeocene: onset of collision, deformation, deltaic progradation, and increased sedimentation rate in the CSB. (d) Late Eocene: Slab tear-related volcanism, progressive deformation in the suture zone and development of a foreland basin (CSB: Central Sakarya Basin, SC: Sakarya Continent, IAO: İzmir-Ankara Ocean, TAP: Tauride-Anatolide Platform, PMS: passive margin sediments).

Yenipazar Formation. As previously suggested, the age of the first tuff by zircon U-Pb dating is $\sim 78.5 \mathrm{Ma}$ in the Göynük section. Additionally, in the Karaardıç section (Ocakoğlu et al. 2007) the youngest pyroclastic bed occurred very close to the base of the Globotruncana aegypticata Zone $(\sim 74.8 \mathrm{Ma})$. In this respect, the younger volcanism spans $\sim 4$ Myr during the middle Campanian. The volcanic products as mapped by Gedik and Aksay (2002) form a grossly E-W belt only $20 \mathrm{~km}$ north of the suture belt (Figure 2).

Although the Pontide magmatic arc is commonly considered to be associated with subduction along the Izmir-Ankara and Intra-Pontide suture zones, temporal and spatial refinement of the existing models still need to be achieved. Apart from the volcanic belt recognized here, located in the CSB, another volcanic belt extends across the southern Black Sea shoreline, $\sim 80 \mathrm{~km}$ north of the study area (Özcan et al. 2012). This magmatism is of early Campanian-early Maastrichtian (84-71 Ma) in age and has been shown to be related to subduction (Karacık and Tüysüz 2010). In the Central Pontides further east, another magmatic arc of late Santonian-middle Campanian age is present, which developed at the northern margin of the Sakarya Terrane and is interpreted to be related to south- vergent Intra-Pontide subduction (Ellero et al. 2015). Since many studies suggested that the Intra-Pontide Ocean was already closed prior to the Santonian (see references in Özcan et al. 2012), the SantonianCampanian arc volcanism in the study area should be related to the subduction of the Neotethys along the Izmir-Ankara subduction zone. We suggest that these two distinct arcs could have been created by a roll-back episode along the Izmir-Ankara subduction zone sometime during the Santonian-Campanian times, but further geochronological constrains on the age of volcanism at both localities are needed to confirm this hypothesis.

\subsection{An extensional mega-structure in the basin interior?}

The map in Figure 2 reveals the E-W trending distribution of the Santonian-Campanian volcanic arc products is grossly sub-parallel to the suture belt in the south. This implies that the volcanic conduits that ejected the voluminous pyroclastics and basaltic lava (Saner 1977, 1980; Göncüoğlu et al. 1996) also lined up E-W direction presumably controlled by nearby major faults. The 
Olistostromal nature of this volcano-sedimentary unit has been previously documented in the west of the Yenipazar town (Duru et al. 2002). Our own observations, shown in Figure 8 demonstrate that the widespread slope failure was active in the middle of the basin during the middle-late Campanian. We suggest that some major E-W trending extensional faults enabled the ascent of the magmatic fluids, which formed the Campanian volcanism, and resulted in submarine relief that caused widespread slumping later on. During collision, these faults were likely re-activated as inverted compressional features (Figure 2). Okay and Altıner (2016) have also envisaged extensional tectonics along the forearc in the Haymana basin, located along the southern tip of the Pontide active margin. These authors favoured an extensional intra-arc realm which trapped siliciclastics sourced from the arc, allowing deep marine carbonate deposition to survive until the Campanian in the Haymana Basin. Based on seismic profiles and kinematic data in the Boyabat-Sinop Basin further NE, Hippolyte et al. (2015) demonstrated early Cretaceous-Palaeocene extensional structures were structurally inverted during the early Eocene as a result of collision and subsequent indentation.

\subsection{Onset of the collision in the Central Sakarya Zone}

Here, we show the deltaic Taraklı sandstones began to be deposited in the early Thanetian $(\sim 61 \mathrm{Ma})$ in an overall progradational pattern and were sourced from the southern margin of the basin. At the southernmost sites in the basin, near Yenipazar, a contemporaneous angular unconformity developed, suggesting uplift of the southern basin margin (Figure 10, 12A, and 13C). This unconformity is absent near Nallıhan, however the first massive deltaic progradation in the Okçular and Nallıhan sections is also dated to the early Thanetian ( $61 \mathrm{Ma}$ ). Therefore, the onset of basin-wide deltaic progradation from the south, and uplift in the Yenipazar area indicate a major episode of uplift of the accretionary prism, which we interpret to be related to the onset of collisional tectonics along the IzmirAnkara Suture. Increased sedimentation rates at this time (Figure 13) substantiate the timing of the onset of collision and the subsequent drainage area widening. The local unconformity near Yenipazar whilst a conformable succession in Nallihan directly to the east can be explained by a protrusion along the suture front.

Previous studies indicated that the Lutetian volcanism (51-47 Ma) at the southern margin of the basin was developed in relation to break-off process of the longago subducted oceanic slab (Kasapoğlu et al. 2016), associated with an extensional episode of the overlying upper crust (Okay and Satır 2006; Altunkaynak and Dilek 2013). The findings of the present study do not support an extensional regime in the CSB during the Lutetian. Instead, our data indicate deposition in a retroarc-foreland basin since the late Palaeocene, which received fluvial, lacustrine and shallow marine sediments until the mid-Lutetian (Figure 14D). Appearance of basaltic lava and reworked lacustrine blocks of middle Eocene age within the late Eocene sedimentary rocks reflects further uplift and denudation of the southern margin, as commonly seen in foreland basins. The CSB follows the same foreland basin evolution as the Central Pontide basins (Leren et al. 2007; Catanzariti et al. 2013; Hippolyte et al. 2015). Contemporaneously, a peripheral arc foreland basin to the south began to develop related to the south-directed reverse faults and thrusts, which has yet to be studied in detail (Figure 14D). Deposition in this basin starts directly on the ophiolitic melange and older rocks (Figure 3) (Gedik and Aksay 2002; Yıldız et al. 2015) contrary to the continuous sedimentation in the CSB throughout the Cretaceous and Palaeogene.

\section{Conclusions}

The present study sheds significant light upon convergent margin geodynamics of the Sakarya Terrane, which evolved from subduction to collision during the late Santonian-Eocene, based on a detailed palaeoenvironmental and biostratigraphic investigation of the infill of the Central Sakarya Basin.

Our findings indicate that deep marine pelagic carbonate deposition was sporadically accompanied by E-W trending submarine volcanism and underwent significant slumping, probably induced by the already commenced subduction in the south. Uplift and subaerial exposure of the accretionary prism related to ongoing subduction triggered deep marine siliciclastic deposition after $79.6 \mathrm{Ma}$. The widening of the exposed accretionary prism along the southern active margin radically raised sedimentation rates and increased the ultramafic influx to the basin in the latest Campanian ( $73 \mathrm{Ma}$ ). From the middle Campanian to the K-Pg boundary, at least 3 widespread submarine fan systems developed across the southern and central part of the basin. In the late Campanian, widespread slumping involving freshly deposited sediments as well as basement rocks is assumed to be related to a longlived extensional structure. Throughout the late Campanian-early Palaeocene period, the sedimentation rate continued to rise and reached the maximum values around the Selandian $(\sim 60 \mathrm{Ma})$. This time period is 
characterized by rapid uplift due to onset of the collision between the Tauride-Anatolide Platform and the Sakarya Terrane in the south, based on a local unconformity and a massive deltaic progradation/terrestrialization across the southern areas of the basin. Our two reconstructed basin fill geotraverses do not display any sedimentary evidence that could witness the occurrence of an active margin in the north throughout the late Santonian-Bartonian period.

Future dating and kinematic studies of the local unconformity in the SW portion of the CSB and the related terrestrial sediments (Kızılçay Formation) will enhance our knowledge about the early collisional processes. Similarly, our suggestion of the long-lived extensional structure in the middle of the basin requires further support by novel kinematic data. Finally the time at which the extensional structure was active must be tuned by more detailed sedimentological and biostratigraphical investigations. These potential data would enrich our existing knowledge on extensional arc/forearc regions.

\section{Highlights}

- Campanian-to-Eocene sediments of the Sakarya Terrain is studied for sedimentology and biostratigraphy

- Subduction-related uplift since Early Campanian is documented

- Alignment of volcanic centres and submarine mass movements indicate an extensional forearc realm

- Rapid siliciclastic progradation northward marks onset of collision in Late Danian

\section{Acknowledgments}

The authors are grateful to Prof Aral Okay (İstanbul Technical University) and an anonymous reviewer for their comments and suggestions that considerably contributed to the manuscript.

\section{Disclosure statement}

No potential conflict of interest was reported by the authors.

\section{Funding}

This work was supported by the Scientific and Technological Research Council of Turkey (TÜBITAK) under Grant 104Y153; National Science Foundation (NSF) under Grant EAR-1543684.

\section{ORCID}

Faruk Ocakoğlu (D) http://orcid.org/0000-0002-4619-5865

\section{References}

Açıkalın, S., Ocakoğlu, F., Yılmaz, İ.Ö., Vonhof, H., Hakyemez, A., and Smit, J., 2016, Stable isotopes and geochemistry of a Campanian-Maastrichtian pelagic succession, MudurnuGöynük Basin, NW Turkey: Implications for palaeoceanography, palaeoclimate and sea-level fluctuation: Palaeogeography, Palaeoclimatology, Palaeoecology, 441, 453-466. DOI:10.1016/j.palaeo.2015.10.005.

Açıkalın, S., Vellekoop, J., Ocakoğlu, F., Yılmaz, I.Ö., Smit, J., Özkan-Altıner, S., Goderis, S., Vonhof, H., Speijer, R.P., Woelders, L., Fornaciari, E., and Brinkhuis, H., 2015, Geochemical and palaeontological characterization of a new K-Pg Boundary locality from the Northern branch of the Neo-Tethys: Mudurnu-Göynük Basin, NW Turkey: Cretaceous Research, 52, 251-267.

Akbayram, K., Şengör, A.C., and Özcan, E., 2016, The evolution of the Intra-Pontide suture: implications of the discovery of Late Cretaceous-Early Tertiary melanges: Geological Society of America Special Papers, 525, SPE525-18.

Altıner, D., Koçyiğit, A., Farinacci, A., Nicosia, U., and Conti, M. A., 1991, Jurassic-Lower Cretaceous stratigraphy and palaeogeographic evolution of the southern part of North-western Anatolia: Geologica Rom, 27, 13-80.

Altınlı, I.E., 1976, Geology of the northern portion of the Middle Sakarya River: İstanbul Üniversitesi Fen Fakültesi Mecm: Seri B, 411-4, 35-56. in Turkish with English abstract

Altunkaynak, Ş., and Dilek, Y., 2013, Eocene mafic volcanism in northern Anatolia: Its causes and mantle sources in the absence of active subduction: International Geology Review, 5513, 1641-1659. DOI:10.1080/00206814.2013.792497.

Anthonissen, D.E., and Ogg, J.G., 2012, Cenozoic and Cretaceous biochronology of planktonic foraminifera and calcareous nannofossils, in Gradstein, F.M., Ogg, J.G., Schmitz, M.D., and Ogg, G. M., eds., The geologic time scale, Elsevier, 1083-1127.

Berggren, W.A., Kent, D.V., Swisher, I.I.I.,.C.C., and Aubry, M.P., 1995, A revised Cenozoic geochronology and chronostratigraphy, in Berggren, W.A., ed., Geochronology Time Scales and Global Stratigraphic Correlation, SEPM Special Publication No. 54, p. 129-212.

Berggren, W.A., and Pearson, P.N., 2005, A revised tropical to subtropical Paleogene planktonic foraminiferal zonation: The Journal of Foraminiferal Research, 354, 279-298. DOI:10.2113/35.4.279.

Besbelli, B., 1991, Adapazarı H25 b1,b4,c1 Paftalarının Jeoloji ve Petrol Olanakları. MTA Genel Müdürlüğü, Report No:9237, p. 54 [in Turkish].

Burnett, J.A., Gallagher, L.T., and Hampton, M.J., 1998, Upper cretaceous, in: Bown P.R., ed., Calcareous Nannofossil Biostratigraphy. British Micropalaeontological Society Series, Chapman \& Hall/Kluwer Academic Publishing, 132-199.

Catanzariti, R., Ellero, A., Göncüoglu, M.C., Marroni, M., Ottria, G., and Pandolfi, L., 2013, The Taraklı Flysch in the Boyali area (Sakarya Terrane, northern Turkey): Implications for the tectonic history of the IntraPontide suture zone: Comptes Rendus Geoscience, 34511-12, 454-461. DOI:10.1016/j.crte.2013.11.001. 
Channell, J.E.T., Tüysüz, O., Bektas, O., and Sengör, A.M.C., 1996, Jurassic-Cretaceous paleomagnetism and paleogeography of the Pontides (Turkey): Tectonics, 151, 201-212. DOI:10.1029/95TC02290.

Çinku, M.C., Hisarlı, Z.M., Heller, F., Orbay, N., and Ustaömer, T., 2011, Middle Eocene paleomagnetic data from the eastern Sakarya Zone and the central Pontides: Implications for the tectonic evolution of north central Anatolia: Tectonics, 301, 1-19. DOI:10.1029/2010TC002705.

Coccioni, R., and Silva, I.P., 2015, Revised Upper AlbianMaastrichtian planktonic foraminiferal biostratigraphy and magneto-stratigraphy of the classical Tethyan Gubbio section (Italy): Newsletters on Stratigraphy, 481, 47-90. DOI:10.1127/nos/2015/0055.

Demirkol, C., 1977, Üzümlü-Tuzaklı (Bilecik) dolayının jeolojisi: Türkiye Jeoloji Kurumu Bülteni, 20, 9-16. in Turkish with English abstract

Duru, M., Gedik, İ., and Aksay, A., 2002, 1/100.000 Ölçekli Türkiye Jeoloji Haritaları. Adapazarı- H24 Paftası İzahnamesi, Maden Tetkik Arama Genel Müdürlüğü Jeoloji Etütleri Dairesi, Ankara, 34, in Turkish with English abstract

Ellero, A., Ottria, G., Sayit, K., Catanzariti, R., Frassi, C., Göncüoğlu, M.C., Marroni, M., and Pandolfi, L., 2015, Geological and geochemical evidence for a Late Cretaceous continental arc in the central Pontides, northern Turkey: Ofioliti, 402, 73-90.

Eroskay, S.O., 1965, Paşalar Boğazı-Gölpazarı Sahasının jeolojisi. İstanbul Üniversitesi Fen Fakültesi Mecmuası, Seri: B, 30, 3-4, 135-170 [in Turkish].

Gedik, İ., and Aksay, A., 2002, 1/100.000 Ölçekli Türkiye Jeoloji Haritaları. Adapazarı-H25 Paftası İzahnamesi, Maden Tetkik Arama Genel Müdürlüğü Jeoloji Etütleri Dairesi, Ankara, 34, in Turkish with English abstract

Genç, Ş.C., and Tüysüz, O., 2010, Tectonic setting of the Jurassic bimodal magmatism in the Sakarya Zone (Central and Western Pontides), Northern Turkey: A geochemical and isotopic approach: Lithos, 1181, 95-111. DOI:10.1016/ j.lithos.2010.03.017.

Göncüoğlu, C., Turhan, N., Şentürk, K., Uysal, S., Özcan, A., and Işık, A., 1996, Geological characteristics of the structural units in Central Sakarya between Nallihan and Saricakaya. Mineral Research and Exploration Institute of Turkey (MTA) Report, No. 10094 [in Turkish].

Göncüoglu, M.C., Marroni, M., Pandolfi, L., Ellero, A., Ottria, G., Catanzariti, R., Tekin, U.K., and Sayit, K., 2014, The Arkot Dağ Mélange in Araç area, central Turkey: Evidence of its origin within the geodynamic evolution of the Intra-Pontide suture zone: Journal of Asian Earth Sciences, 85, 117-139. DOI:10.1016/j.jseaes.2014.01.013.

Göncüoglu, M.C., Sayit, K., and Tekin, U.K., 2010, Oceanization of the northern Neotethys: Geochemical evidence from ophiolitic melange basalts within the Izmir-Ankara suture belt, NW Turkey: Lithos, 1161, 175-187. DOI:10.1016/j. lithos.2010.01.007.

Göncüoğlu, M.C., Turhan, N., Şentürk, K., Özcan, A., Uysal, Ş., and Yaliniz, M.K., 2000, A geotraverse across northwestern Turkey: Tectonic units of the Central Sakarya region and their tectonic evolution: Geological Society, London, Special Publications, 1731, 139-161. DOI:10.1144/GSL. SP.2000.173.01.06.

Gradstein, F.M., 2016, Geologic Time Scale, in Harff J., Meschede M., Petersen S., Thiede J., eds., Encyclopedia of
Marine Geosciences. Encyclopedia of Series Earth Sciences. Springer, Dordrecht, doi:https://doi.org/10.1007/978-94007-6238-1.

Granit, Y., and Tintant, H., 1960, Observation preliminaires sur le Jurassic de la région de Bilecik, CR Acad. Science, 251: 1801-1803 [in Turkish].

Hardenbol, J.A.N., Thierry, J., Farley, M.B., Jacquin, T., De Graciansky, P.C., and Vail, P.R., 1998, Mesozoic and Cenozoic Sequence Chronostratigraphic Framework of European Basins, in Graciansky, P.C., et al., eds., Mesozoic and Cenozoic Sequence Stratigraphy of European Basins, SEPM Special Publication 60, Tulsa, Charts 1-8, 3-13.

Hippolyte, J.C., Espurt, N., Kaymakci, N., Sangu, E., and Müller, C., 2015, Cross-sectional anatomy and geodynamic evolution of the Central Pontide orogenic belt (northern Turkey). International Journal of Earth Sciences: Geologische Rundschau, 1051, 81.

Hippolyte, J.C., Müller, C., Kaymakci, N., and Sangu, E., 2010, Dating of the Black Sea Basin: New nannoplankton ages from its inverted margin in the Central Pontides (Turkey): Geological Society, London, Special Publications, 3401, 113-136. DOI:10.1144/SP340.7.

Karacık, Z., and Tüysüz, O., 2010, Petrogenesis of the Late Cretaceous Demirköy Igneous Complex in the NW Turkey: Implications for magma genesis in the Strandja Zone: Lithos, 1143, 369-384. DOI:10.1016/j. lithos.2009.09.012.

Kasapoğlu, B., Ersoy, Y.E., Uysal, İ., Palmer, M.R., Zack, T., Koralay, E.O., and Karlsson, A., 2016, The petrology of Paleogene volcanism in the Central Sakarya, Nallıhan Region: Implications for the initiation and evolution of post-collisional, slab break-off-related magmatic activity: Lithos, 246p, 81-98. DOI:10.1016/j.lithos.2015.12.024.

Kazancı, N., 1979, Haramiköy konglomeralarının sedimanter özellikleri (Nallıhan KD/Ankara): Türkiye Jeoloji Kurumu, 22, 69-76.

Koçyiğit, A., Altıner, D., Farinacci, A., Nicosia, U., and Conti, A., 1991, Late Triassic - Aptian Evolution of The Sakarya Divergent Margin: Implications For The Openning History of The Northern Neo-Tethys, In Northwestern Anatolia, Turkey: Geologica Rom, 27, 13-80.

Leren, B.L., Janbu, N.E., Nemec, W., Kirman, E., and Ilgar, A., 2007, Late Cretaceous to early Eocene sedimentation in the Sinop-Boyabat basin, north-central Turkey: A deep-water turbiditic system evolving into littoral carbonate platform, in Sedimentary Processes, Environments and Basins: A Tribute to Peter Friend. Nichols, G., Paola, C., and Williams, E.A., eds., IAS Special Publication 38, p. 401456.

Licht, A., Coster, P., Ocakoğlu, F., Campbell, C., Métais, G., Mulch, A., Taylor, M., and Beard, K.C., 2017, Tectono-stratigraphy of the Orhaniye Basin, Turkey: Implications for collision chronology and Paleogene biogeography of central Anatolia: Journal of Asian Earth Sciences, 143, 45-58. DOI:10.1016/j.jseaes.2017.03.033.

Ludwig, K.R., 2003, User's manual for Isoplot 3.00: A geochronological toolkit for Microsoft Excel (No. 4). Berkeley Geochronology Center, Special Publication No. 4, $74 \mathrm{pp}$.

Meijers, M.J., Kaymakci, N., Van Hinsbergen, D.J., Langereis, C. G., Stephenson, R.A., and Hippolyte, J.C., 2010, Late Cretaceous to Paleocene oroclinal bending in the central 
Pontides (Turkey): Tectonics, 294, 1-21. DOI:10.1029/ 2009TC002620.

Nairn, S.P., Robertson, A.H., Ünlügenç, U.C., Tasli, K., and İnan, N., 2013, Tectonostratigraphic evolution of the Upper Cretaceous-Cenozoic central Anatolian basins: An integrated study of diachronous ocean basin closure and continental collision: Geological Society, London, Special Publications, 3721, 343-384. DOI:10.1144/SP372.9.

Ocakoğlu, F., 1995, Orhaniye-Güvenç (KB Ankara) karasal çökellerinin Paleosen-Erken Eosen sedimanter evrimi: Geological Bulletin of Turkey, 382, 53-66.

Ocakoğlu, F., and Açıkalın, S., 2009, Paleoclimatic and Source Area Investigation of the Cretaceous-Tertiary Deposits of the Central Sakarya Region, Eskişehir Osmangazi University Research Project no: 200715024, Commission for the Scientific Researches, Eskişehir, Turkey

Ocakoğlu, F., Açıkalın, S., and Yılmaz, i.Ö., 2009, A sequence stratigraphic approach to the Mid-Campanian submarine fan development in the Mudurnu-Göynük Basin, NW Anatolia, 8th International Symposium on the Cretaceous System, University of Plymouth, UK, Abstract Book, p. 148.

Ocakoğlu, F., Açıkalın, S., Yılmaz, İ.Ö., Şafak, Ü., and Gökçeoğlu, C., 2012, Evidence of orbital forcing in lake-level fluctuations in the Middle Eocene oil shale-bearing lacustrine successions in the Mudurnu-Göynük Basin, NW Anatolia: Journal of Asian Earth Sciences, 56p, 54-71. DOI:10.1016/j. jseaes.2012.04.021.

Ocakoğlu, F., Yılmaz, i.Ö., Demircan, H., Altıner, Ö.S., Hakyemez, A., İslamoğlu, Y., ... Szulc, A., 2007, Orta Sakarya Bölgesi Geç Kretase-Paleojen Çökellerinin Sekans Stratigrafisi. The Scientific and Technological Research Council of Turkey (TUBiTAK, Project no: 104Y153), Final Report (450 pp. [in Turkish with English abstract].

Ocakoğlu, F., Yılmaz, I..Ö., and Özkan-Altıner, S., 2013, MidCampanian Submarine Fan Development in the MudurnuGoynuk Basin (NW Anatolia): A Sequence Stratigraphic Framework. 9th Internation Symposium on the Cretaceous System, METU, Ankara, Abstract Book, 81-82,

Ogg, J.G., Hinnov, L.A., and Huang, C., 2012, Cretaceous, in Gradstein, F.M., Ogg, J.G., Schmitz, M.D., and Ogg, G.M., eds., The geologic time scale, p. 793-853.

Okay, A., and Satır, M., 2006, Geochronology of Eocene plutonism and metamorphism in northwest: Geodinamica Acta, 195, 251-266. DOI:10.3166/ga.19.251-266.

Okay, A.I., 1984, Distribution and characteristics of the northwest Turkish blueschists: Geological Society, London, Special Publications, 171, 455-466. DOI:10.1144/GSL. SP.1984.017.01.33.

Okay, A.l., 2008, Geology of Turkey: A synopsis: Anschnitt, 21, 19-42.

Okay, A.l., Harris, N.B., and Kelley, S.P., 1998, Exhumation of blueschists along a Tethyan suture in northwest Turkey: Tectonophysics, 2853, 275-299. DOI:10.1016/S0040-1951(97) 00275-8.

Okay, A.I., Sunal, G., Sherlock, S., Altiner, D., Tüysüz, O., Kylander-Clark, A.R., and Aygül, M., 2013, Early Cretaceous sedimentation and orogeny on the active margin of Eurasia: Southern Central Pontides, Turkey: Tectonics, 325, 1247-1271. DOI:10.1002/tect.20077.

Okay, A.I., Tansel, İ., and Tüysüz, O., 2001, Obduction, subduction and collision as reflected in the Upper CretaceousLower Eocene sedimentary record of western Turkey:
Geological Magazine, 1382, 117-142. DOI:10.1017/ S0016756801005088.

Okay, A.l., and Tüysüz, O., 1999, Tethyan sutures of northern Turkey: Geological Society, London, Special Publications, 1561, 475-515. DOI:10.1144/GSL.SP.1999.156.01.22.

Önal, M., Helvacı, C., İnci, U., Yağmurlu, F., Meriç, E., and İzver, T., 1988, Çayırhan kuzeybatı Ankara kuzeyindeki Soğukçam kireçtaşı, Nardin formasyonu ve Kızılçay grubunun stratigrafisi, yaşı, fasiyesi ve depolanma ortamları: TPJD Bülteni, 12, 153-163.

Ottria, G., Pandolfi, L., Catanzariti, R., Da Prato, S., Ellero, A., Frassi, C., Göncüoğlu, M.C., Marroni, M., Ruffini, L., and Sayit, K., 2017, Evolution of an early Eocene pull-apart basin in the Central Pontides (Northern Turkey): New insights into the origin of the North Anatolian Shear Zone: Terra Nova, 296, 392-400. DOI:10.1111/ter.2017.29.issue-6.

Özcan, Z., Okay, A., Özcan, E., Hakyemez, A., and ÖzkanAltıner, S., 2012, Late Cretaceous-Eocene geological evolution of the Pontides based on new stratigraphic and palaeontologic data between the Black Sea coast and Bursa (NW Turkey): Turkish Journal of Earth Sciences, 216, 933-960.

Petrizzo, M.R., Falzoni, F., and Silva, I.P., 2011, Identification of the base of the lower-to-middle Campanian Globotruncana ventricosa Zone: Comments on reliability and global correlations: Cretaceous Research, 323, 387-405. DOI:10.1016/j. cretres.2011.01.010.

Robaszynski, F., and Caron, M., 1995, Foraminiferes planctoniques du Cretace; commentaire de la zonation EuropeMediterranee: Bulletin De La Société Géologique De France, 1666, 681-692.

Robertson, A.H., and Ustaömer, T., 2004, Tectonic evolution of the Intra-Pontide suture zone in the Armutlu Peninsula, NW Turkey: Tectonophysics, 3811, 175-209. DOI:10.1016/j. tecto.2002.06.002.

Saner, S., 1977, Geyve - Osmaneli - Gölpazarı - Taraklı Alanının Jeolojisi; Eski Çökelme Ortamları ve Çökelmenin Evrimi. MTA Report No: 6306, 312 pp.

Saner, S., 1980, Paleogeography and sedimentary environment of the Jurassic and younger sequences of the Mudurnu-Göynük basin: Türkiye Jeoloji Kurumu Bülteni, 23, 39-52.

Sarı, A., and Aliyev, S.A., 2005, Source rock evaluation of the lacustrine oil shale bearing deposits: Göynük/Bolu, Turkey: Energy Resources, 27p, 279-298. DOI:10.1080/00908310490441980.

Şengör, A.M.C., and Yılmaz, Y., 1981, Tethyan evolution of Turkey: A plate tectonic approach: Tectonophysics, 75, 181-241. DOI:10.1016/0040-1951(81)90275-4.

Şeker, H., and Kesgin, Y., 1991, Nallıhan - Mudurnu - Seben Beypazarı Arasında Kalan Bölgenin Jeolojisi ve Petrol Olanakları: TPAO Arama Grubu Başkanlığı no:2907, 42 pp [unpublished report in Turkish].

Sherlock, S., Kelley, S., Inger, S., Harris, N., and Okay, A., 1999, $40 \mathrm{Ar}-39 \mathrm{Ar}$ and $\mathrm{Rb}-\mathrm{Sr}$ geochronology of high-pressure metamorphism and exhumation history of the Tavsanli Zone, NW Turkey: Contributions to Mineralogy and Petrology, 1371, 46-58

Tansel, ì., 1980, Nallıhan ve Dolayının Biyostratigrafi Incelemesi. Yerbilimleri Dergisi, Hacettepe Üniversitesi Yerbilimleri Uygulama ve Araştırma Merkezi, v. 5-6, 31-47 [in Turkish with English abstract].

Timur, E., and Aksay, A., 2002, 1/100.000 Ölçekli Türkiye Jeoloji Haritaları. Adapazarı- H26 Paftası İzahnamesi, Maden Tetkik 
Arama Genel Müdürlüğü Jeoloji Etütleri Dairesi, Ankara, 30, in Turkish with English abstract

Turhan, N., 2002, 1/500.000 scale geological maps of TurkeyAnkara sheet, Mineral Research and Exploration (MTA) General Directorate, Ankara.

Tüysüz, O., 1999, Geology of the Cretaceous sedimentary basins of the Western Pontides: Geological Journal, 341-2, 75-93. DOI:10.1002/(SICI)1099-1034(199901/06)34:1/2<75:: AID-GJ815>3.0.CO;2-S.

Wade, B.S., Pearson, P.N., Berggren, W.A., and Pälike, H., 2011, Review and revision of Cenozoic tropical planktonic foraminiferal biostratigraphy and calibration to the geomagnetic polarity and astronomical time scale: Earth-Science Reviews, 1041-3, 111-142. DOI:10.1016/j.earscirev.2010.09.003.

Wolfgring, E., Wagreich, M., Dinarès-Turell, J., Yilmaz, I.O., and Böhm, K., 2017, Plankton biostratigraphy and magnetostratigraphy of the Santonian-Campanian boundary interval in the Mudurnu-Göynük Basin, northwestern Turkey: Cretaceous Research, DOI:10.1016/j.cretres.2017.07.006.

Yıldız, A., Kibici, Y., Bağci, M., Dumlupunar, İ., Kocabaş, C., and Aritan, A.E., 2015, Petrogenesis of the post-collisional Eocene volcanic rocks from the Central Sakarya Zone (Northwestern Anatolia, Turkey): Implications for Source Characteristics, Magma Evolution, and Tectonic Setting. Arabian Journal of Geosciences, 812, 11239-11260.

Yılmaz, I.Ö., 2008, Cretaceous pelagic red beds and black shales (Aptian-Santonian), NW Turkey: Global Oceanic Anoxic and Oxic Events: Turkish Journal of Earth Sciences, 172, 263-296.

Yılmaz, İ.O., Altıner, D., and Ocakoğlu, F., 2016, Upper JurassicLower Cretaceous depositional environments and evolution of the Bilecik (Sakarya Zone) and Tauride carbonate platforms, Turkey: Palaeogeography, Palaeoclimatology, Palaeoecology, 449, 321-340. DOI:10.1016/j.palaeo.2016.02.028. 